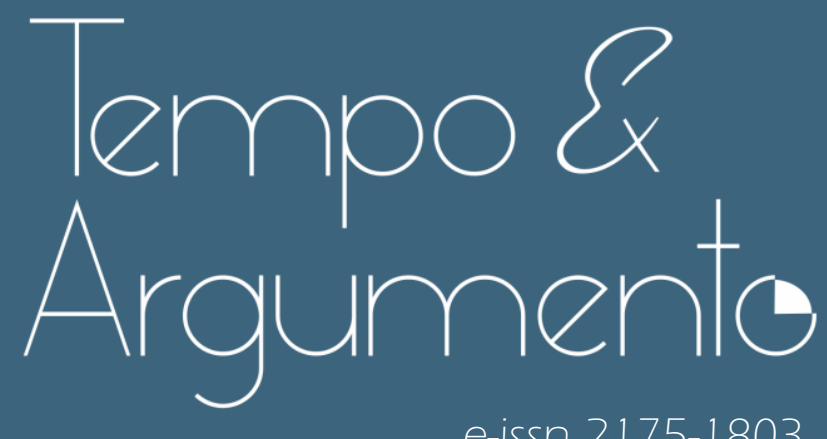

e-issn 2175-1803

\title{
Irrigando a Ditadura: facetas da modernização agrícola no Brasil (1964-1975)
}

- Mário Martins Viana Júnior

Doutor em História pela Universidade Federal de Santa Catarina (UFSC).

Professor do Programa de Pós-Graduação em História (PPGH) da Universidade Federal do Ceará (UFC). Coordenador do Núcleo de Estudos sobre Memória e Conflitos Territoriais (COMTER).

Fortaleza, CE - BRASIL

lattes.cnpq.br/0484147709183592

mario_ufc@hotmail.com

(iD) orcid.org/0000-0001-5957-7021

Para citar este artigo:

VIANA JÚNIOR, Mário Martins. Irrigando a Ditadura: facetas da modernização agricola no Brasil (1964-1975). Tempo e Argumento, Florianópolis, v. 12, n. 30, e0209, maio/ago. 2020.

doi http://dx.doi.org/10.5965/2175180312302020e0209

Recebido: 16/06/2020

Aprovado: 02/08/2020 


\title{
Irrigando a Ditadura: facetas da modernização agrícola no Brasil (1964-1975)
}

\begin{abstract}
Resumo
Neste artigo investigamos como a implantação de uma modernização agrícola no Brasil, a partir da década de 1960, esteve atrelada ao endividamento do país e à expansão do controle e das atividades persecutórias do Estado ditatorial. Para tanto, analisamos principalmente os contratos, estabelecidos entre o Estado e firmas nacionais e estrangeiras, focados na implantação do paradigma da Revolução Verde no Brasil e, em específico, do regadio no Nordeste brasileiro. Entre os contratos analisados, focamos naqueles voltados para a modernização agrícola, o que significou $41 \%$ dos documentos. A partir desse corpus documental, pudemos identificar cinco tipos de ações, dentre as quais demos ênfase aos trabalhos de infraestrutura e pesquisas. Foram analisadas também as políticas públicas do período voltadas para a irrigação, em especial o Programa de Integração Nacional (PIN) e o Programa Plurianual de Irrigação (PPI), que projetam a região Nordeste brasileira como alvo de ações intervencionistas para a construção de distritos de irrigação. Por fim, examinamos alguns isomorfismos entre o Departamento Nacional de Obras Contra as Secas (DNOCS) e o Serviço Nacional de Informações (SNI), que indicam que aquele órgão possa ter servido aos objetivos persecutórios ditatoriais sobre as populações do campo.
\end{abstract}

Palavras-chave: Inovações agrícolas. Brasil - Condições econômicas. Ditadura. Irrigação agrícola.

\section{Irrigating the Dictatorship: facets of the agricultural modernization in Brazil (1964-1975)}

\begin{abstract}
In this article, we investigate how, from the 1960's, the implementation of an agricultural modernization in Brazil was linked to the country's indebtedness and to the expansion of controls as well as to the persecutory activities of the dictatorial State. To this aim, we mainly analyze the contracts, settled between the State and national as well as foreign firms, focused on the implementation of the Green Revolution paradigm in Brazil and, specifically, on the irrigation of Brazilian Northeast. Among the contracts analyzed, we focused on those aiming at the agricultural modernization, encompassing $41 \%$ of the documents. From this corpus of documents, we were able to identify five types of actions, among which we gave emphasis to research and infrastructure efforts. We also analyzed the public policies of the period stressing irrigation, especially the National Integration Program (NIP) and the Pluriannual Irrigation Program (PIP), projecting the Brazilian Northeast region as a target for interventionist actions in order to build irrigation districts. Finally, we examined some isomorphisms between the National Department of Works Against Drought (DWAD) and the National Information Service (NIS), that indicate the agency may have served the dictatorial persecutory objectives against populations in the countryside.
\end{abstract}

Keywords: Agricultural Modernization. Indebtedness. Dictatorship. Irrigation. 


\section{Introdução1}

A hipótese central avançada neste artigo é que um conjunto de aspectos e intervenções tomados como modernização do setor agropecuário no Brasil, a partir de apreciação focada na região Nordeste, auxiliou e foi auxiliado pelo endividamento externo do país. Concomitantemente, isto esteve relacionado a uma agenda maior de controle, produção de informações e formas diversificadas de perseguição operadas pelo Estado ditatorial e seus agentes nos projetos de expansão de áreas irrigadas.

Apesar de os estudos sobre o endividamento brasileiro apontarem que houve um deslocamento majoritário de recursos para setores específicos e privilegiados, como infraestrutura, indústria e tecnologia (FATORELLI, 2013; SERVILHA, 1994), demonstraremos como os financiamentos e empréstimos focados no desenvolvimento agropecuário no período ditatorial compuseram sim um importante vetor, ainda que careçam de maior investigação histórica. Nesse movimento investigativo-analítico escrutinaremos como atuaram alguns dos agentes, grupos e cadeias de financiamentos e órgãos focados no desenvolvimento rural.

Para tanto, metodologicamente, escrutinamos e sistematizamos uma densa documentação produzida pelo Estado, expressa mormente nos registros do Departamento Nacional de Obras Contra as Secas (DNOCS). Referimo-nos, por um lado, aos contratos assumidos ou mediados por esta autarquia, envolvendo outras instituições estatais e empresas nacionais e estrangeiras. Através destes documentos foi possível mapear os principais interesses e as áreas de atuação do Estado em ações voltadas para a ampliação da área irrigada no Nordeste brasileiro. Concomitantemente, analisamos os "Estudos de Viabilidade" entregues pelas empresas contratadas. Estas fontes trazem registros pormenorizados das populações do campo pelas ações dos investigadores, em áreas de instalação de distritos ou perímetros de irrigação, e permitem refletir sobre formas diversas de viǵlia e controle do Estado autoritário.

\footnotetext{
${ }^{1}$ Este artigo é fruto de pesquisa desenvolvida em nível de pós-doutoramento, sem financiamento, iniciada na Universidade Nova de Lisboa e concluída na Universidade de Coimbra, em Portugal, sob supervisão da professora Dulce Freire, entre agosto de 2019 e julho de 2020.
} 
O recorte temporal escolhido, 1964-1975, é um imperativo das fontes, dado que todos os livros de contratos, arduamente encontrados, remetem a este período. ${ }^{2}$ Já o contexto nordestino em destaque diz respeito à atenção especial e privilegiada recebida por esta região nas políticas públicas de irrigação para o período, conforme demonstraremos a seguir.

No âmbito historiográfico, observamos que a temática da irrigação no país ainda é pouco tratada. Quando muito, analisada ou assinalada como subitem de investigações mais amplas, a exemplo dos importantes estudos sobre "modernização da agricultura" (GONÇALVES NETO, 1997; SZMRECSÁNYI, 1994; DELGADO, 2002; SANTOS, 2002; MENDONÇA, 2009), "crédito e extensão rural"3 (MENDONÇA, 1997; 2010; OLIVEIRA, 2013), “desenvolvimento rural” e expansão da "Revolução Verde” (MENDONÇA, 2010; PEREIRA, 2010), entre outros.

Em verdade, os percursos e as diretrizes das políticas sobre irrigação no Brasil tornaram-se objeto de estudo privilegiado em outras áreas, como na Geografia (ANDRADE, 1983; LEME, 1999; PALHETA et al., 1991; IORIS, 2010; COELHO NETO, 2010), com destaque para a Geografia Agrária. Entre os/as economistas a avaliação em retrospecto sobre a irrigação costumeiramente pôs em análise as políticas nacionais de recursos hídricos para pensar o uso racional da água (LIMA, 1999) e debater a irrigação como forma de desenvolvimento regional, principalmente no Nordeste (KAGEYAMA et al., 1989; ABLAS, 1988; BISERRA et al., 1989).

Esses trabalhos de outras áreas são de significativa importância para o entendimento das formas de apropriação e transformação da água como recurso hídrico, concatenados com a análise da expansão e desenvolvimento do

\footnotetext{
2 Importante observarmos que a referida documentação foi encontrada em meio a uma enorme massa documental composta por milhares de documentos amontoados e sem qualquer tratamento arquivístico. A totalidade desses documentos foi transferida para um galpão após a desapropriação da área onde funcionava a Coordenadoria Estadual do Departamento Nacional de Obras Contras as Secas (DNOCS), na cidade de Fortaleza, no ano de 2009, para a construção daquele que seria $03^{\circ}$ maior aquário do mundo pelo Governo do Estado do Ceará. Após uma década, tanto o aquário não foi construído como os documentos permanecem em um galpão do DNOCS expostos à ação de raios solares, águas de chuvas, poeira, umidade, fungos, circulação de animais, entre outros.

${ }^{3}$ De acordo com Sonia Regina de Mendonça (2013, p. 2) há na historiografia relativa à "era Vargas" três vícios contumazes. Aqui, merece destaque o vício indicado em relação ao lugar da agricultura na análise dos historiadores/as. Os estudos sobre políticas públicas agrícolas/agrárias tenderiam a se concentrar no pós-1960, isto é, em períodos recentes, "[...] obstaculizando uma visão de conjunto [...]”.
} 
capitalismo no Brasil. Grosso modo, contudo, as narrativas projetam uma forma de conhecimento, hegemônico, sobre a irrigação no país caracterizada por abordagens que primam pelo etapismo e pela cronologia, a exemplo da abordagem histórica através de fases e grandes sínteses ${ }^{4}$ e semelhante às explicações tautológicas oficiais (BRASIL, 2008).

O exercício de análise que propomos aqui, evidentemente, dialoga com esses estudos, mas busca avançar em outras frentes. Nomeadamente, partimos da problematização sobre as formas de alinhamento e das consequências das articulações entre capital nacional e internacional com o Estado ditatorial brasileiro, o que nos aproximou de estudos que ampliam a interpretação sobre o regime militar como uma ditadura civil-militar (DREIFUSS, 1981), dado o envolvimento de setores específicos da sociedade civil, como o empresariado, e seus pactos que ajudaram a construir e manter o regime (LEMOS, 2010; CAMPOS, 2014).

Assim, além do ineditismo das fontes tratadas para o âmbito historiográfico, este trabalho busca contribuir com uma análise sobre a irrigação do país para além do seu prisma técnico. Dito de outra maneira, buscamos compreender como o Estado autoritário se aliançou ao capital nacional e internacional para o alcance de seus objetivos persecutórios através da expansão da Revolução Verde no país; como este capital se serviu dessas alianças para ampliar sua participação, influência e riqueza; e como essas relações mútuas contribuíram para aumentar o endividamento do país.

\section{Modernização agrícola no Brasil}

Em meados do século XX desponta um fenômeno mundialmente conhecido como "revolução agrícola contemporânea" ou "Revolução Verde". No âmbito da concepção e produção agropecuária, materializava-se principalmente na alta motorização-mecanização, além da “[...] seleção de variedades de plantas e [animais], ampla utilização dos fertilizantes, dos alimentos concentrados para

\footnotetext{
${ }^{4}$ Como exemplo, podemos assinalar o trabalho de Ioris (2010), que propõe uma análise histórica da apropriação econômica dos recursos hídricos a partir de duas grandes fases: a fase desenvolvimentista (a água como mecanismo indireto de acumulação - com forte inserção da irrigação comercial), e a fase neoliberal (a água como mecanismo direto e indireto de acumulação).
} 
- gado e produtos de tratamento das plantas e dos animais domésticos" (MAZOYER; ROUDART, 2010, p. 27).

Esse movimento concretizou a convergência de objetivos do governo estadunidense e de interesses privados daquele país, a exemplo da incisiva atuação das Fundações Ford e da Fundação Rockefeller e do Banco Mundial (BM). Calcadas no aparato tecnológico e científico, essas ações fizeram parte da expansão imperialista transformando "[...] economias e paisagens em todo o mundo, [e tornando-se] o modelo de desenvolvimento agrícola internacional e elemento central da política externa norte-americana no período da Guerra Fria" (WRIGHT, 2012, p. 135).

Nos países capitalistas periféricos houve ampla recepção dos paradigmas da modernização da agricultura, desvelando suas reais intenções: "a maximização do lucro, através da monopolização de fatias cada vez maiores do mercado; e a aquisição de royalty, por intermédio dos pacotes tecnológicos" (ANDRADES; GANIMI, 2007, p. 44). Segundo Virgínia Fontes (2010, p. 184), nestes territórios, a Revolução Verde foi projetada ainda para "[...] borrar da história as revoluções vermelhas" com foco na potencialização da produção de culturas de exportação. Para tanto, tinha como alicerces a expropriação dos povos do campo e o uso de maquinário, além da relação intrínseca de dependência entre água e insumos químicos, cujo consumo através de produção interna, e principalmente através de importações, aumentou sensivelmente, conforme podemos visualizar no Gráfico 1:

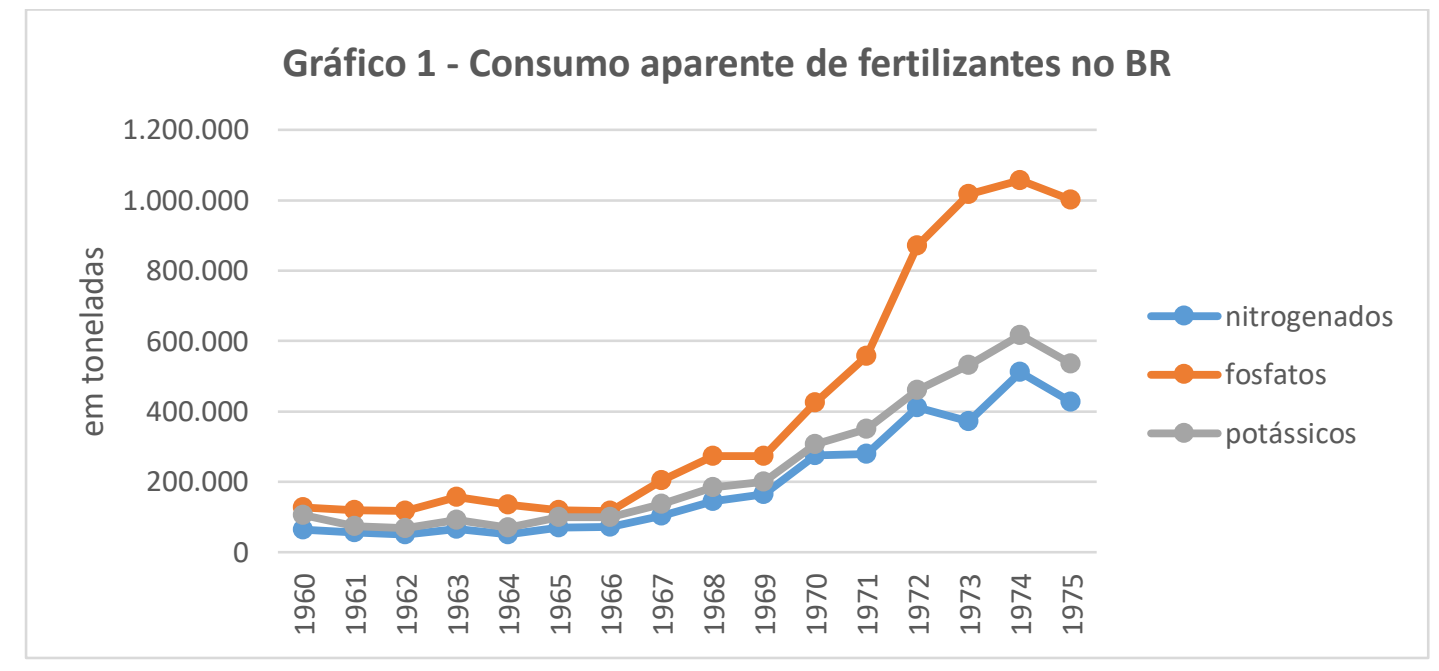

Fonte: Elaborado a partir de Revista do BNDE, jul./dez de 1977. 
O Estado autoritário brasileiro foi um importante catalisador desse processo. Investiu fortemente em estruturas de disciplinamento de água para fins de irrigação. Assim, o movimento iniciado no regime democrático das décadas de 1950 e 60, e que tinha como pretenso foco o desenvolvimento da região Nordeste do país, foi capturado, transformado e agudizado no período ditatorial (1964-1985), conforme já observado por lanni.

Mais uma vez, o capital reconquistava o Nordeste de forma ampla. Desde o começo, esse Estado foi levado a favorecer, de forma maciça e ostensiva, o grande capital, a burguesia regional, nacional e estrangeira. O que já era um processo notável, antes de 1964, com a atuação do DNOCS, IAA, BNB e Sudene e outros órgãos do poder público, desde o golpe de Estado se tornou um processo escancarado. (IANNI, 1981, p. 117)

Nesse contexto, o debate sobre a questão agrária foi suplantado pelo pensamento funcionalista norte-americano no tocante aos papéis clássicos da agricultura para o desenvolvimento econômico. Segundo Delgado:

As chamadas cinco funções da agricultura: liberar mão-de-obra para a indústria; gerar oferta adequada de alimentos; suprir matérias-primas para indústrias; elevar as exportações agrícolas; transferir renda real para o setor urbano estavam impregnadas na imaginação dos economistas conservadores da época, e também na de alguns críticos do sistema, de forma que somente se reconheceria problemas ou crise agrícola onde algumas dessas funções não estivessem sendo sistemática e adequadamente atendidas. (DELGADO, 2001, p. 161-162)

A modernização agrícola conservadora, isto é, que conservava e intensificava a estrutura fundiária existente foi acrescida de expansão expressiva do crédito rural, o que esteve relacionado à intensificação da desigualdade no campo através de processos de desapropriação, expropriação, expulsão e outras formas de violência (GONÇALVES NETO, 1997). Em paralelo, houve uma drenagem dos recursos pelos beneficiários de pagamentos e créditos, como empresários e latifundiários (SERVILHA, 1994).

O Estado autoritário e seus agentes compuseram um conjunto variado de políticas públicas, programas e projetos voltados para a transformação do mundo rural (BURSZTYN, 2008). Mereceu atenção o crédito rural (Sistema Nacional de Crédito Rural-1965) e toda a cadeia de atividades envolvidas nas 
formas de produção modernas voltadas para a agricultura capitalista, como a extensão rural (MENDONÇA, 2010). Para termos uma ideia da sua importância na agenda político-econômica do país, a participação do Tesouro Nacional nos financiamentos do setor agropecuário só iria sofrer retração na segunda metade da década de 1980 (RAMOS; MARTHA JÚNIOR, 2010).

Nesse contexto, a irrigação ganhou notoriedade e se tornou objeto de ações vultosas, como o Programa de Integração Nacional (PIN $\left.{ }^{5}\right)$ de 1970 e o Programa Plurianual de Irrigação (PPI) de 1971. Estes possibilitaram a multiplicação da área irrigada do país bem como de ações de extensão rural, pesquisa, serviços, fornecimento, ampliação na produção/importação de insumos químicos e, sobretudo, na sua transformação infraestrutural. De acordo com Coelho Neto, o PPI é o:

[...] documento que estabelece as diretrizes nacionais para a política de irrigação no país [...] este programa representa um marco na mudança de orientação do Estado brasileiro em relação à agricultura irrigada, pois, estabelece metas a serem perseguidas pelo Estado e busca a ampliação do conhecimento sobre os recursos disponíveis, resultando na elaboração de diversos estudos de viabilidade técnica e econômica. [...] O PPI define uma geografia para a política nacional de irrigação, circunscrevendo suas ações prioritariamente pela região Nordeste, envolvendo todas as bacias hidrográficas, e pelas regiões Sudeste e Sul, na bacia do rio Paraná [com o] estabelecimento de diretrizes e metas comandadas pelo setor público, mas estimulando a iniciativa privada. (COELHO NETO, 2010, p. 4)

\footnotetext{
${ }^{5}$ Este Programa surgiu no contexto da grande seca de 1970. Dirigia-se aos estados do Norte e Nordeste do Brasil com o objetivo de integrar aquelas regiões à economia nacional em uma situação de urgência. Isso significou um elevado deslocamento de recursos para as regiões referidas que foram disputados por grupos regionais e empresas nacionais e estrangeiras. Ao lado de outros recursos administrados pelo DNOCS, o PIN foi a principal fonte de recurso de pesquisas na área de irrigação (ver Gráfico 7). Nesse Programa estava inserida ainda a "primeira fase do plano de irrigação do Nordeste", o que garantiu a realização de um amplo conjunto de estudos e obras. Na constituição dos recursos do PIN, estavam previstos ainda "empréstimos de instituições financeiras nacionais e internacionais", o que nos indica a possibilidade de que os pagamentos desses contratos, em parte ou na íntegra, podem ter sido fruto de endividamento do Estado brasileiro. Afinal, superintendências e autarquias federais, como a Superintendência do Desenvolvimento do Nordeste (SUDENE) e o DNOCS, compunham o rol de estatais que tinham autonomia para a contratação de empréstimos. Consultar: BRASIL. Decreto-Lei $n^{\circ}$ 1.106, de 16 de junho de 1970. Disponível em: https://www2.camara.leg.br/legin/fed/declei/1970-1979/decreto-lei-1106-16-junho-1970-
} 375379-publicacaooriginal-1-pe.html. Acesso em: 24/07/2020. 
Através deste programa foram avaliados 73 projetos de irrigação e aprovados 64 para a captação de recursos via MINTER e/ou empréstimos externos. Dentre estes, 56 projetos remeteram ao Nordeste com a incorporação de 195 mil hectares, e apenas 8 ao Sul e Sudeste, embora estes projetassem uma área de 172 mil hectares para irrigação (BRASIL, 1971, p. 8). Nesse contexto de proeminência da região Nordeste, a seleção e encaminhamento de projetos de irrigação pelo PPI foram fortalecidos pela transferência e alocação de recursos, através do PIN, dos orçamentos de órgãos como o Departamento Nacional de Obras Contra as Secas (DNOCS), a Superintendência do Desenvolvimento do Nordeste (SUDENE), e pela participação de estados, fundos, ministérios, entre outros, conforme poderemos observar mais adiante no Gráfico 7.

\section{Recursos: investimentos e endividamento}

Kennedy [...] precisou que o Plano de desenvolvimento elaborado pelo governo de Brasília representará uma despesa total de 900.000.000,00 de dólares num período de cinco anos. Quinhentos milhões serão entregues ao Brasil e 126 milhões por diversas instituições financeiras internacionais, como o Banco Interamericano de Desenvolvimento. (US\$..., 1961, p. 1).

A ida do diretor da Superintendência do Desenvolvimento do Nordeste (SUDENE) a Washington, em abril de 1961, resultou em ampla cobertura realizada pelo Jornal do Commercio. O periódico nacional relatava os objetivos da comitiva de informar acerca dos planos de desenvolvimento para o Nordeste brasileiro; a boa impressão causada pelo diretor Celso Furtado; e a ginástica política operada em encontros com “[...] todas as personalidades importantes da administração de Kennedy, assim como os representantes dos organismos financeiros internacionais". (US\$..., 1961, p. 1).

De fato, os contatos com o próprio John F. Kennedy, com o presidente do Banco Mundial e com dirigentes dos Fundos de Desenvolvimento Econômico dos EUA, entre outros, fizeram o governo estadunidense declarar como prioritárias as demandas do Brasil e correlacionadas aos objetivos da "Aliança para o Progresso", tornando-se o principal credor do Brasil e desempenhando função crucial nas negociações (LOUREIRO, 2012). Assim, o governo daquele país se 
comprometia a trabalhar na concessão de vultosas somas, através de empréstimos e envio de mantimentos, sob o argumento de melhorar a vida da população miserável e de afastar o "fantasma do comunismo" da América Latina. (PINTO, 1964, p. 3).

Não obstante declaração em contrário, a comitiva brasileira tentava inserir os planos de transformação do Nordeste brasileiro no fluxo dos financiamentos e investimentos externos. A estratégia dos brasileiros não estava descolada da realidade no contexto dos anos 1950-60. Em 1958, Juscelino Kubitschek havia lançado a Operação Pan-Americana (OPA), e, apenas um mês depois da visita da comitiva, em agosto de 1961, haveria a reunião no Uruguai para a assinatura da Carta de Punta del Este. Também o Banco Mundial passou a atuar como financiador das grandes empresas difusoras da Revolução Verde, além da propagação de centros de pesquisa pelo mundo apoiados pelas Fundação Ford e Rockefeller (PEREIRA, 2010).

A Carta de Punta del Este foi assinada pelos EUA e outras 22 nações do hemisfério ocidental para a formalização da Aliança para o Progresso em plena Guerra Fria e diante dos temores da expansão da Revolução socialista cubana (1959). Seguiam-se as diretrizes de Kennedy para a expansão imperialista em um "programa de assistência ao desenvolvimento socioeconômico da América Latina”, através da entrada de recursos estadunidenses administrados pela Agência dos Estados Unidos para o Desenvolvimento Internacional (USAID) e pelo Banco Interamericano de Desenvolvimento (BID).

Somado aos fundos públicos, os Investimentos Diretos Estrangeiros (IED) resultaram em importantes fontes de financiamento e garantias para órgãos e empresas no Brasil. A comitiva brasileira muito provavelmente tinha ciência que a entrada de capitais estrangeiros nos anos 1950 havia sido elevada, com destaque para a atuação de instituições europeias e estadunidenses (MOLINA, 2016). O volume de investimentos e reinvestimentos não apenas foi garantido, como continuou e foi ampliado nas décadas seguintes, inclusive com incentivo das autoridades monetárias brasileiras. A seguir, destacamos as oito principais origens de investimentos e reinvestimentos até 1985 de empresas dos EUA 
(18,1\%), Alemanha (8\%), Suíça (4,7\%), Reino Unido (3,3\%), Canadá (2,9\%), Panamá (2,7\%), Itália (2,2\%) e França (2,1\%), conforme exposto no Gráfico 2:

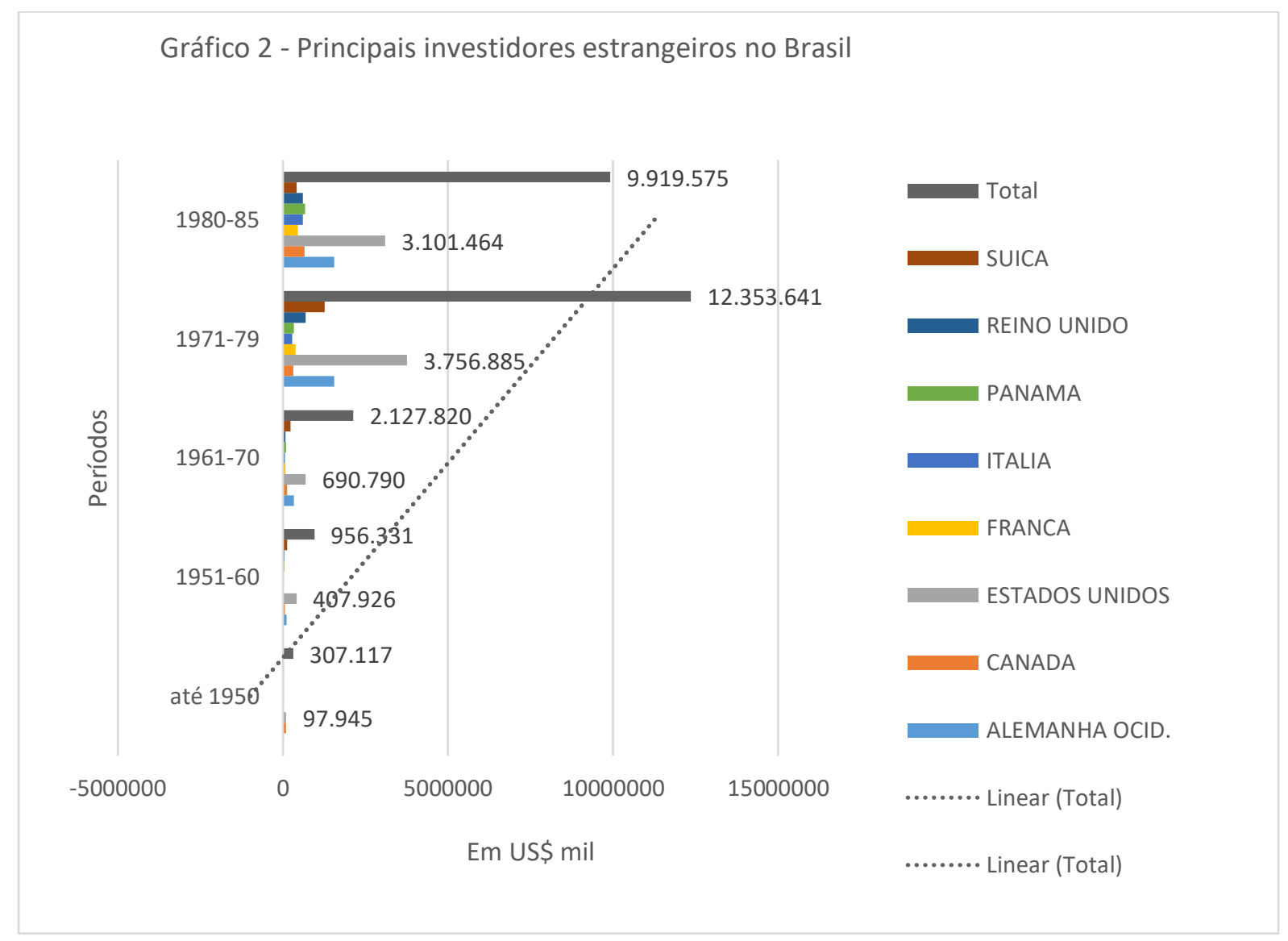

Fonte: Elaborado a partir de BACEN / FIRCE / DIVAP, em 31/12/19856.

Além da ampliação destes IED, os anos 1960-70 foram marcados por reformas institucionais no sistema financeiro com elevada expansão da dívida externa, conforme podemos observar no Gráfico 3. Isto se deu através da atuação do Estado enquanto devedor-credor e como estimulador de setores que considerava estratégicos (infraestrutura e tecnologia), submetendo outras áreas que dependiam fortemente de subsídios (exportador e agrícola). Ademais, a partir dos anos 60, as grandes empresas estatais passaram a realizar pedidos de empréstimos diretos, principalmente ao BM/BID, seguindo uma tendência de aprofundamento do endividamento brasileiro nos anos 1970 em relação a outros bancos (ABREU et al., 1995).

\footnotetext{
${ }^{6}$ Disponível em: https://www.bcb.gov.br/rex/ied/port/Pa\%C3\%ADsDaEmpresa-Ano-5085/Htms/PAISES-EMPRESA-ANO-50-85.asp?idpai=INVEDIR\&frame=1. Acesso em 04/06/2020.
} 


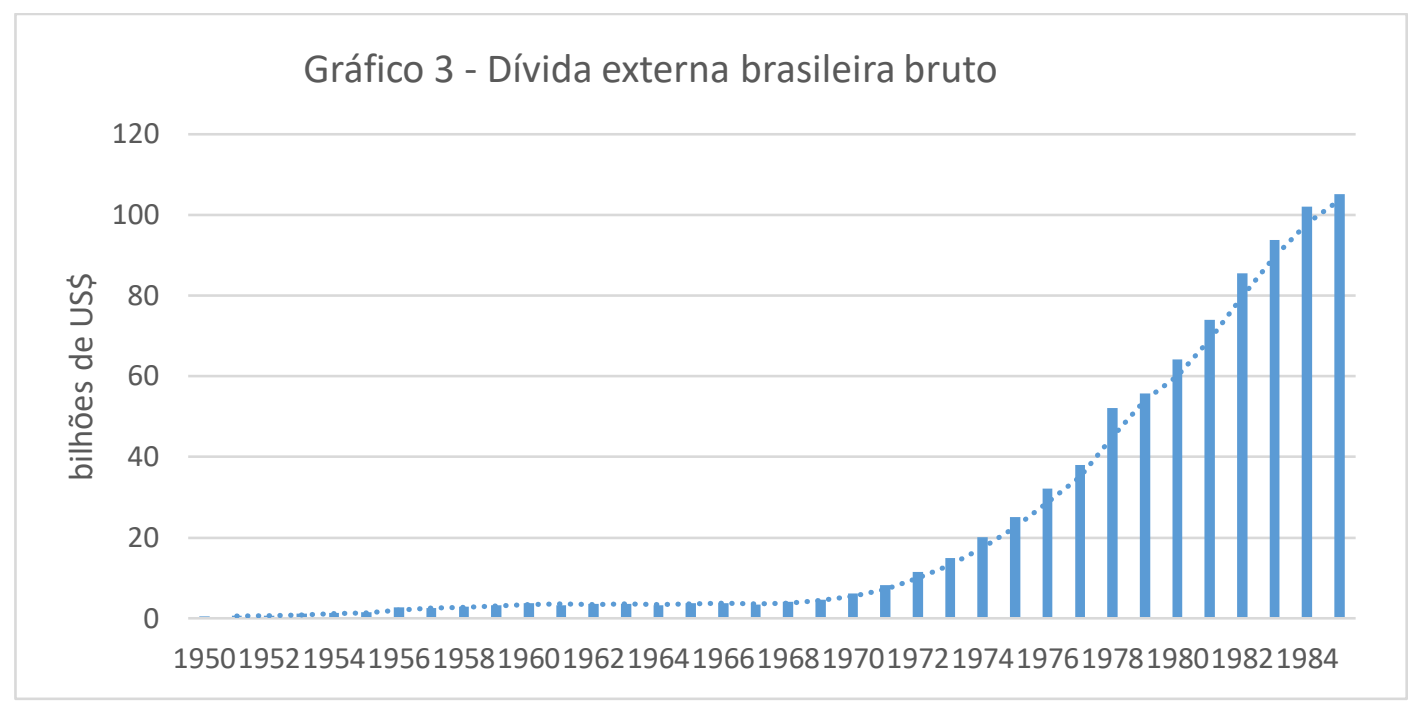

Fonte: Elaborado a partir do Ipeadata, em 25/05/2020.

É fato que os estoques de IED foram alocados preferencialmente em alguns setores (infraestruturais, indústria, tecnologia, etc.) em comparação ao agropecuário. De forma semelhante, existem análises que escrutinam como o crédito rural foi pensado e operacionalizado ao longos das décadas de 1960-1970 (SERVILHA, 1994), mostrando suas fontes de financiamento a partir de (1) forte participação estatal por subsídios e créditos, (2) controle governamental através da obrigação dos depósitos de bancos comerciais e da administração e (3) gerenciamento de fundos, programas e projetos (OLIVEIRA; MONTEZANO, 1982).

Existe, contudo, uma zona nebulosa que carece de maior investigação. Em 1980, por exemplo, 75\% dos créditos decorridos das Autoridades Monetárias não possuíam fontes de recursos especificadas (SERVILHA, 1994). A transferência de recursos para atividades no espaço rural envolvia outros agentes, grupos e cadeias de financiamentos e órgãos que não especificamente o crédito rural pelo SNCR. Foram realizados acordos internacionais multilaterais e contratos entre instituições públicas brasileiras com agências externas (a exemplo de empresas altamente especializadas no ramo da irrigação) e bancos, difíceis de serem rastreados. Ademais houve a entrada de recursos estrangeiros, nem sempre detalhados, via programas e projetos, como o Programa de Integração Nacional (PIN), os quais o empresariado nacional e internacional disputou.

\footnotetext{
${ }^{7}$ Disponível em: http://www.ipeadata.gov.br/ExibeSerie.aspx?serid=38367. Acesso em 04/06/2020.
} 


\section{A irrigação em disputa pelo capital}

Engenharia apoia novo decreto-lei. O Clube de Engenharia enviou congratulações ao Ministério dos Transportes pelo seu apoio à engenharia brasileira com a promulgação do Decreto-lei n 64.345. O decreto institui normas para a contratação de serviços de firmas de engenharia e de consulta técnica, objetivando o desenvolvimento da engenharia nacional, prevendo a contratação dos serviços de engenharia e consultoria técnica pela administração federal com empresas nacionais ou então com empresas estrangeiras que tenham pelo menos metade de brasileiros no seu corpo técnico. (ENGENHARIA..., 1969, p. 6).

O Decreto-lei n 64.345 de 3/06/1969 foi um ponto de saturação que significou o atendimento das demandas do empresariado brasileiro voltado para o setor da infraestrutura e que se via ameaçado pela presença estrangeira no país. O Decreto definia as atividades do setor e normatizava a contratação, sob o argumento de desenvolver a engenharia nacional. Na prática, as firmas internacionais poderiam ser contratadas para atividades somente quando não houvesse empresa nacional qualificada e capacitada para o desempenho dos serviços a realizar. ${ }^{8}$ Isto criava a necessidade de os estrangeiros se aliançarem aos empresários brasileiros através de consórcios ou mediante participação como acionistas das empresas. Estava garantido o quinhão dos empresários nacionais.

A expertise daqueles ligados ao Clube de Engenharia se mostrou eficiente ao longo das décadas. Houve ascensão, manutenção e ampliação da riqueza dos grupos e pessoas ligadas ao ramo da infraestrutura pesada durante a ditadura civil-militar brasileira com forte colaboração do Estado e do capital internacional (CAMPOS, 2014). Isso não foi diferente na parte de transformações estruturais do setor agropecuário, sobretudo para o aproveitamento dos recursos hídricos, conforme observado por Márcio Pereira em seu estudo sobre o Banco Mundial:

\footnotetext{
8 Dentre os 616 contratos firmados com a participação do DNOCS entre os anos de 1964-1975, 254 remetiam à modernização agrícola e 38 sinalizaram relações internacionais, divididos da seguinte forma: Espanha (11 contratos), EUA (7), França (6), Japão (3), Portugal (3), Israel (3), Itália (2), Alemanha (1), Checoslováquia (1) e Áustria (1). Estes contratos envolveram a quantia de Cr\$ 73.818.951,07 ou US\$16.052.864,72. Departamento Nacional de Obras Contra as Secas (DNOCS), Livros de Contratos, 1964-1975.
} 
De longe, irrigação, drenagem e administração de água foi o principal subsetor dentro da agropecuária financiado pelo Banco nos anos 1950 e 1960, e continuou assim nos anos 1970, principalmente na Ásia, no Oriente Médio e na América Latina. A maior parte do aumento da produção agrícola dos países da periferia vinha de áreas irrigadas novas ou reabilitadas. Os insumos da Revolução Verde, sobretudo fertilizantes químicos, requeriam uma hidrologia altamente favorável e o Banco cumpriu o papel de pivô nesse processo. (PEREIRA, 2010, p. 191, grifo nosso.)

A década de 1960 constitui assim um marco nas mudanças das formas de concepção e tratamento da questão hídrica no país. A descontinuidade, expressa através de ações pontuais e isoladas da primeira metade do século XX, foi substituída por um planejamento nacional com maior alocação de recursos pelo Estado autoritário intervencionista que elegeu como prioridade o desenvolvimento de áreas irrigadas. Nesse contexto houve a criação do Grupo de Estudos Integrados de Irrigação e Desenvolvimento Agrícola (GEIDA), “[...] com orientações que produziram efeitos até o final da primeira metade dos anos 80", quando enfim aconteceu a regulamentação da primeira Lei de Irrigação do Brasil (Lei no 6.662 de 1979) (RODRIGUEZ, 2008, p. 10).

O principal documento constituído em relação ao GEIDA foi o Programa Plurianual de Irrigação (PPI), em 1970, que, apesar de política pública, foi elaborado por duas empresas do ramo, uma nacional (Sondotécnica) e outra israelense (TAHAL), a partir de financiamento concedido por esta última. O PPI se tornou parâmetro balizador e catalisador da expansão da irrigação no país até 1984, ao reunir e cadastrar empresas como critério para execução de atividades, e ao condensar e fomentar os projetos de irrigação de interesse do Estado em todo o território nacional. Foi, inclusive, incorporado aos famigerados Planos Nacionais de Desenvolvimento (PNDs) da ditadura que visavam "colocar o Brasil entre as nações desenvolvidas no espaço de uma geração" (ABREU, [20--]), com foco, entre outros, no setor agropecuário. 
Gráfico 4 - Área Irrigada do Brasil 1950-1995 (em 1.000 hectares)

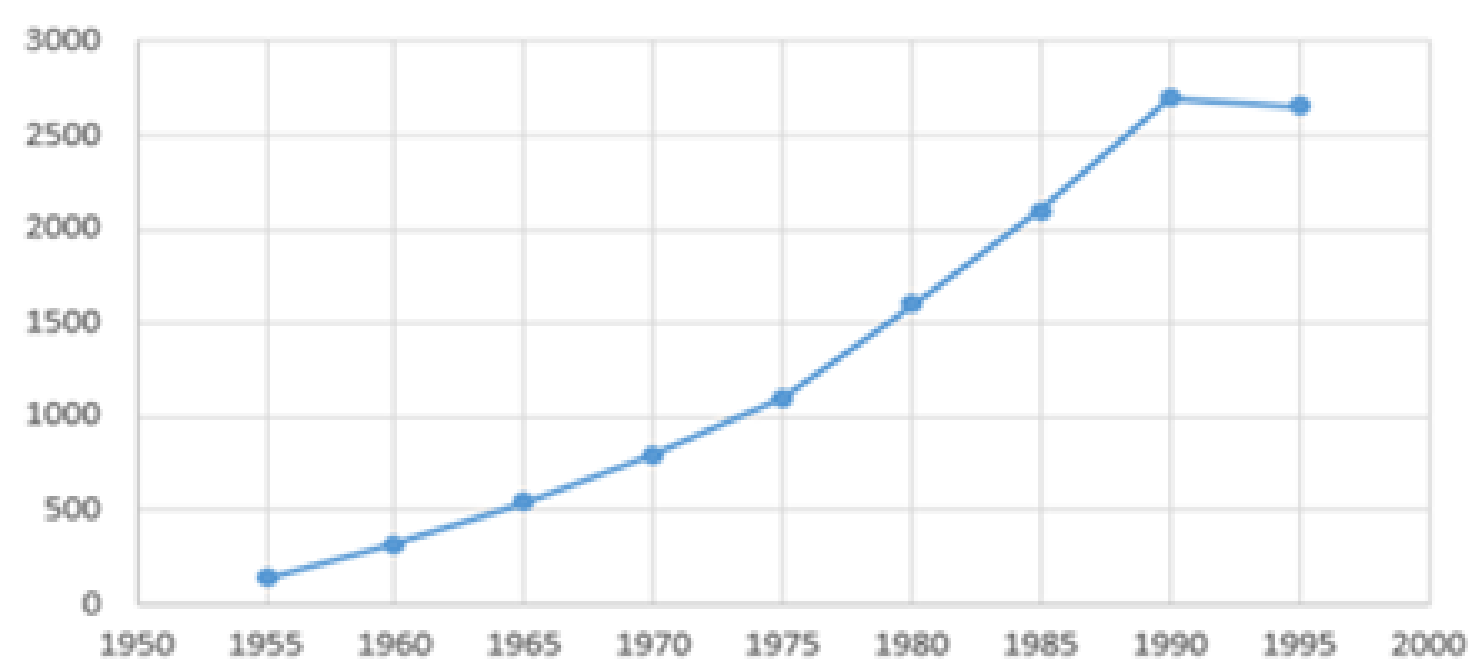

Fonte: Elaborado a partir de Coelho Neto (2010)

Os resultados dessas ações articuladas radicalizaram a espacialização hídrica do país. A área irrigada que representava menos de 200 mil hectares em 1955 já era 796 mil em 1970 e alcançava 2 milhões e 100 mil hectares em 1985. Um crescimento de mais de 100\% em 30 anos, conforme podemos observar no Gráfico 4.

Dessa forma, o delineamento da agricultura capitalista no Brasil estava intimamente interligado à ampliação de produção e importação de outros produtos e bens. Concomitantemente à ampliação da área irrigada houve uma dinamização da indústria de produção de colheitadeiras, caminhões e tratores. Estes, por exemplo, saltaram de 165.870 em 1970 para 665.280 em 1985 (IBGE, [198-]). Com a elevação do maquinário e controle da água administrada nas áreas irrigadas, o subsetor de produção/importação de fertilizantes foi semelhantemente ampliado, conforme vimos no Gráfico 1. Terra, água, fertilizantes, maquinário e produção voltada para o exterior com intensa desapropriação e expropriação no campo. Em linhas gerais, eis o desenho da modernização agropecuária no Brasil. 


\section{Nordeste brasileiro: um laboratório para o controle e tecnologia irrigada}

O Nordeste brasileiro constitui um importante território para entendermos as minudências desse processo, pois se tornou um verdadeiro laboratório de atuação do Estado ditatorial e de empresas privadas. A organicidade capitaneada para o setor agropecuário pelo Estado criou pastas, como o Ministério do Interior (1967), e preservou e ampliou instituições já existentes, como a Superintendência do Desenvolvimento do Nordeste (SUDENE-1959) e o Departamento Nacional de Obras Contra as Secas (DNOCS-1909). Este, nominalmente conhecido como órgão de combate às secas, se tornou um propulsor da Revolução Verde no semiárido brasileiro através do estímulo, execução, fiscalização e administração de recursos e pessoas, além de transformações da estrutura hídrica e escrutínio e identificação das populações do campo.

No período de 1964 a 1975 encontramos 616 documentos referentes a contratos/convênios operados ou mediados pelo DNOCS e registrados pela Procuradoria Geral da União. São eles que nos informam a centralidade que a modernização agrícola recebeu do Estado e do capital privado. Metodologicamente, dividimos a documentação em cinco tipos, o que auxiliou na construção de análises gráficas, apresentadas adiante, e que assim foram agrupados: as ações administrativas totalizaram 154 registros (tipo 1; 25\%); ações de socorros públicos/combate às secas 90 (tipo 2; 14,6\%); técnico geral 83 (tipo 3; 13,5\%); programas diversos 31 (tipo 4; 5\%); e modernização agrícola 254 (tipo 5) ou $41,2 \%$ dos contratos (Ver Gráfico 5).

Em um esforço analítico, um primeiro aspecto que observamos foi a distribuição dos contratos ao longo dos anos. Conforme podemos visualizar no Gráfico 5, enquanto o intervalo imediato pós-golpe, entre 1964-68, foi marcado pela constância dos contratos administrativos e técnicos gerais (tipos 1 e 3), seguido pelo ano de 1969 sem qualquer registro transcrito, o período seguinte ganhou destaque por uma majoração das ações de implantação das áreas irrigadas e de atividades voltadas para o combate às secas (tipos 2 e 5). O pico isolado no ano de 1970 de ações do tipo 2 indica o impacto da grande estiagem naquele ano para a transferência de recursos no seu enfrentamento. E a 
elevação, cume, correção e manutenção de contratos no âmbito da modernização, enquanto tipologia com o maior número de registros (tipo 5), assinalam a repercussão de políticas públicas, como o PPI e o PIN, demonstrando a importância assumida por este setor na agenda nacional para a região Nordeste.

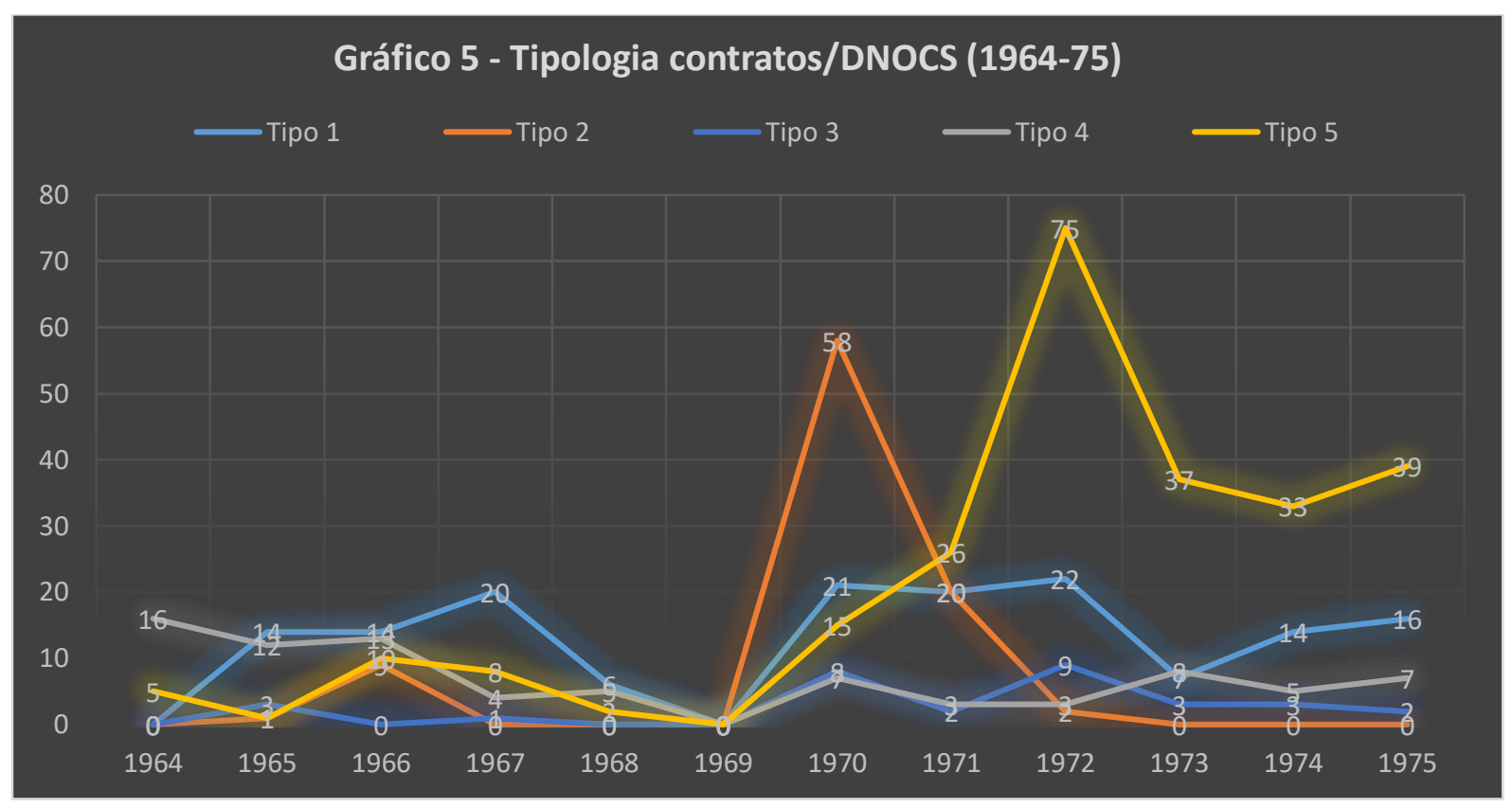

Fonte: Elaborado a partir dos livros de contratos do DNOCS (1964-1965).

O escrutínio das ações de tipo 5, objeto principal deste artigo, permite perceber também formas de concepção e operacionalização das transformações no âmbito rural. A tipologia 5 pode ser entendida como uma canalização das atenções para o desenvolvimento de uma sólida e robusta infraestrutura irrigada, acompanhada por atividades de pesquisa e expedientes de extensão rural, além da contratação de serviços especializados para a construção de diques, canais, represas, entre outros, e para a aquisição de material importado.

Todos estes aspectos compuseram os contratos de tipo 5. E são eles que dão volume à tendência altista da linha amarela no Gráfico 5 a partir de 1970, com topo no ano de 1975, seguida por uma correção e constância no número de contratações nos anos de 1973, 1974 e 1975, em confluência com os alvos expressos no PIN e no PPI. A movimentação da linha amarela neste gráfico representa, na realidade, a multiplicação de ações voltadas para a consecução 
do objetivo de modernização agrícola no Nordeste através da criação de vários perímetros ou distritos de irrigação.

Para uma melhor compreensão, metodologicamente, dividimos os 254 registros de contratos que compõem a tipologia 5 (modernização agrícola) em seis subtipologias, conforme exposto no Gráfico 6, agrupados na seguinte ordem de importância: infraestrutura (41\%), realização de pesquisas/estudos/programas (33\%), atividades de extensão rural (12\%), serviços/recursos humanos (8\%) e fornecimento de material (6\%):

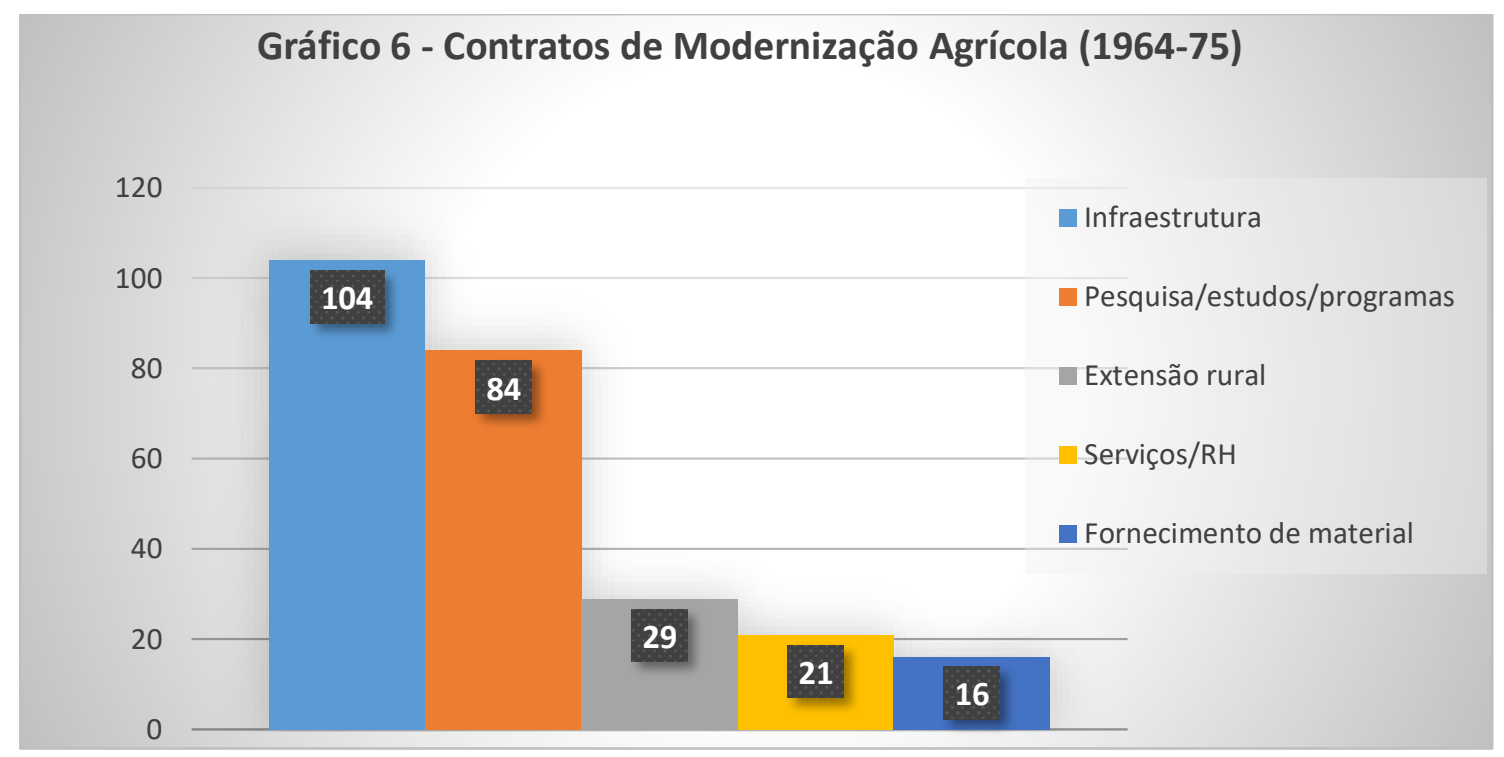

Fonte: Elaborado a partir dos livros de contratos do DNOCS (1964-1965).

Os trabalhos de infraestrutura descritos nos contratos remeteram a um conjunto de operações complexas e de grande porte, como ações de desmatamento, movimentação de terra, desobstrução dos solos; edificação de barragens, diques, comportas, canais, redes de drenagem; constituição e implantação de estações agrometereológicas; pavimentação de estradas; construção de casas, armazéns, escolas e praças para trabalhadores do DNOCS, empresas e populações atingidas pelos projetos, entre outros. Influenciados pelo PPI e PIN, esses contratos representaram a materialização da seleção dos principais projetos do país, o que resultou no aumento do número de barragens e na multiplicação dos distritos de irrigação, principalmente no estado do Ceará.

Tais distritos, na prática, eram/são grandes faixas de terra desapropriadas pelo Estado para fins de utilidade pública. Expulsos os antigos habitantes e 
banidas as suas práticas agrícolas tradicionais, a nova configuração hídrica significou também a investigação da vida pretérita e a seleção de sujeitos para habitarem os Perímetros Irrigados em regime de colonato administrados pelo DNOCS. Estes sujeitos, bem como técnicos, associações e empresas estavam sob a vigília e as diretrizes do Estado autoritário que posicionava agentes dentro das áreas irrigadas para gerenciamento das atividades (BRAGA, 2003). Daí a importância assumida pela outra subtipologia "pesquisas/estudos/programas" em atividades de pedologia, hidrologia, climatologia, agronomia, entre outros; e pelos contratos que possibilitaram a intensificação da "extensão rural" com foco no treinamento dos agricultores.

\section{A pesquisa hidroagrícola}

O âmbito das pesquisas contratadas esteve voltado fundamentalmente para investigações hidroagrícolas (71\% dos contratos deste tipo), sem olvidar pesquisas sobre saúde (17\%) e estudos socioeconômicos (12\%). Assim, a implantação dos espaços irrigados envolvia um conjunto de áreas diferentes diversificando o peso atribuído à engenharia civil das décadas anteriores focada na construção de barragens.

Neste novo cenário, a ascensão da agronomia voltada para a irrigação foi fundamental para o implemento dos pacotes tecnológicos. A otimização do uso da área irrigada dependia da infraestrutura e de conhecimentos sobre solo, fauna, flora, clima, etc., com destaque para o estudo de pragas locais. Formou-se então uma geração de pesquisadores e professores que gradativamente foi se aproximando da matriz estadunidense ${ }^{9}$. Enviados ao exterior passaram a ter uma educação parametrizada pelos ditames da agricultura capitalista que deveria ser replicada em âmbito nacional.

\footnotetext{
${ }^{9}$ Foram encontrados 23 contratos/convênios envolvendo a Universidade Federal do Ceará (UFC), 1 convênio com a Fundação Universidade Regional do Nordeste (FURN) e 1 convênio com a Faculdade Dom Aureliano Matos (FAFIDAM-Limoeiro do Norte). DNOCS, Livros de Contrato, 19641975. Livro 1, fls. 15, 65v, 81v, 87, 105, 113v, 125. Livro 6, fl. 60v. Livro 9, fl. 191. Livro 1.3, fls. 1v, 16, 19, 20, 30, 34, 39, 48, 54, 55, 56, 57, 67, 69, 82. Livro 1.5, fl. 40v.
} 
A preocupação com a multiplicação de áreas irrigadas e a necessidade de pessoal especializado fez o Ministério do Interior procurar o auxílio de organismos internacionais como o BID, o Centro Interamericano de Desenvolvimento Integrado de Aguas e Terras da OEA (CIDIAT), o Instituto Interamericano de Ciências Agrícolas (IICA) e Universidades nacionais e internacionais, "para a realização de cursos curtos de alcance operativo imediato" (SOUSA; BARRIOS, 1974, p. 4). Estudos cooperados entre órgãos brasileiros e a FAO sobre tecnologia de agricultura irrigada formaram mais uma página na propagação da Revolução Verde no Brasil a partir dos anos 1960.

O treinamento dos colonos dos perímetros irrigados era uma etapa fundamental para o sucesso do setor. Assim, a preocupação acadêmica com a pesquisa e a inserção de novas disciplinas nos currículos das escolas de agronomia, como hidrologia aplicada e planejamento de recursos hídricos, não estava isolada. Possuía relação com a aprendizagem direcionada aos trabalhadores. Esta questão envolvia uma cadeia de instituições, empresas, bancos, universidades, associações, fundações e estados. Mobilizava muitos recursos financeiros e de pessoal.

O Gráfico 7 demonstra como a maior parte dos valores para cobertura dos estudos e pesquisas provinha principalmente de duas fontes: DNOCS (41 contratos) e PIN (31 contratos). Simultaneamente o DNOCS deslocava somas de seu próprio orçamento, editais, projetos e programas relacionados, a partir de dois ministérios: Ministério do Interior e Ministério de Viação e Obras Públicas. Também operava com títulos da dívida pública como garantia para os contratos. Semelhantemente o PIN era acionado para garantir o financiamento das pesquisas, desvelando o caminho escolhido para o setor agropecuário pelo Governo Federal. Ainda na esfera pública, havia a participação de recursos dos Estados, Fundos, Ministério da Saúde e SUDENE. Eis a arquitetura financeira que viabilizava as transformações registradas nos contratos, mas que dependia ainda de outras engrenagens. 


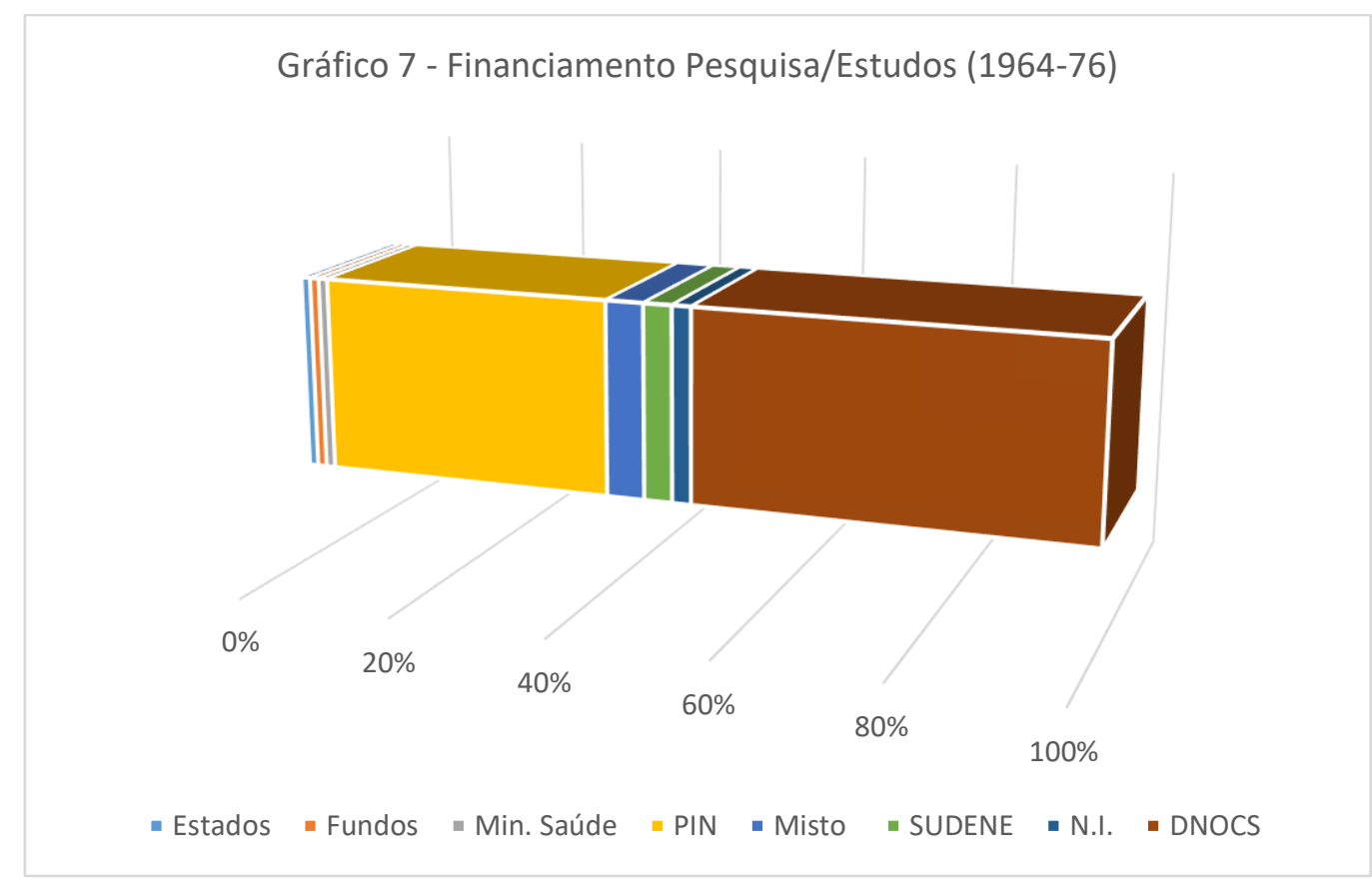

Fonte: Elaborado a partir dos livros de contratos do DNOCS (1964-1965).

Elaborado diante da seca de 1970, o PIN focava na transformação dos estados das regiões Norte e Nordeste buscando realizar "a colonização e o assentamento de grandes contingentes populacionais na Amazônia” (IANNI, 1981, p. 119), através da construção das rodovias Transamazônica, Cuiabá-Santarém, entre outras. Movimentando vultosas somas este programa se tornou uma das plataformas da "catástrofe militar", dada a ampla destruição por desmatamento que mobilizou na Amazônia (MARQUES, 2015).

A ocupação da população castigada pela seca também foi objeto da “primeira fase do plano de irrigação do Nordeste”, integrado ao PIN (BRASIL, 1970). Nele foram alocadas rubricas que viabilizaram estudos e pesquisas apontados nos contratos como "investimentos" e "serviço em regime de programação especial". Foi por este caminho que se deu a contratação de empresas e de consórcios formados por firmas brasileiras e estrangeiras para a realização de trabalhos direcionados ao desenvolvimento da irrigação e escrutínio das populações do campo.

Em 1971, por exemplo, o consórcio das empresas nacionais Organização e Engenharia S/A (OESA) e Engenharia e Tecnologia do Solo e Materiais S/A 
(TECNOSOLO) e as firmas espanholas Oficina Tecnicas de Empresas e Ingenieria S/L (OTI) e Estudios y Projectos Tecnicos e Industriales S/A (EPTISA) firmaram contrato para realização de estudos de reconhecimento do Vale do Gurgeia, no estado do Piauí, com a finalidade de projetos de irrigação (BRASIL, [197-a]). O contrato milionário (CR\$3.999.000,00 ou US\$756.383,58) seria rateado entre os dois grupos de empresas, cabendo às brasileiras 58\% e às espanholas 42\% do volume total a ser convertido em pesetas espanholas e enviado à Espanha. Concomitantemente estava garantida a maior fatia dos pagamentos ao empresariado nacional em acordo com o Decreto-lei n 64.345 de 3/06/1969, conforme abordamos acima, e a transferência de valores para o exterior.

Embora fosse o setor público que administrasse esses recursos, o PIN e as dotações orçamentárias de autarquias como o DNOCS assumiam a possibilidade do financiamento externo mediante endividamento da União e dos estados. Esta engrenagem na arquitetura financeira dos contratos apontava para o endividamento do Estado brasileiro na execução das atividades aqui arroladas. No Programa de Integração Nacional, o artigo $4^{\circ}$, em específico, explicitava que os recursos seriam constituídos, entre outras fontes, por "empréstimos de instituições financeiras nacionais e internacionais" (BRASIL, 1970).

Este dado é bastante relevante pois a maior parte dos recursos dos contratos analisados advinha, a partir de 1971, tanto do Ministério do Planejamento/PIN como do DNOCS, conforme podemos observar no Gráfico 8. Desta forma, assumia-se a possibilidade da entrada de capitais estrangeiros no delineamento das atividades de pesquisa e infraestrutura para irrigação no Brasil. Embora tenhamos encontrado poucos contratos com citação de financiamento direto, como os praticados pela USAID/CONTAP/SUBIN ${ }^{10}$, isso não significava que os empréstimos externos fossem baixos. O capital internacional operava por muitas vias, conforme assegurado pela legislação em vigor.

\footnotetext{
${ }^{10}$ Ver: DNOCS, Livros de Contrato, 1964-1975, Livro 6, fls. 109, 131; Livro 9, 36v; Livro 1.324 v e 25.
} 


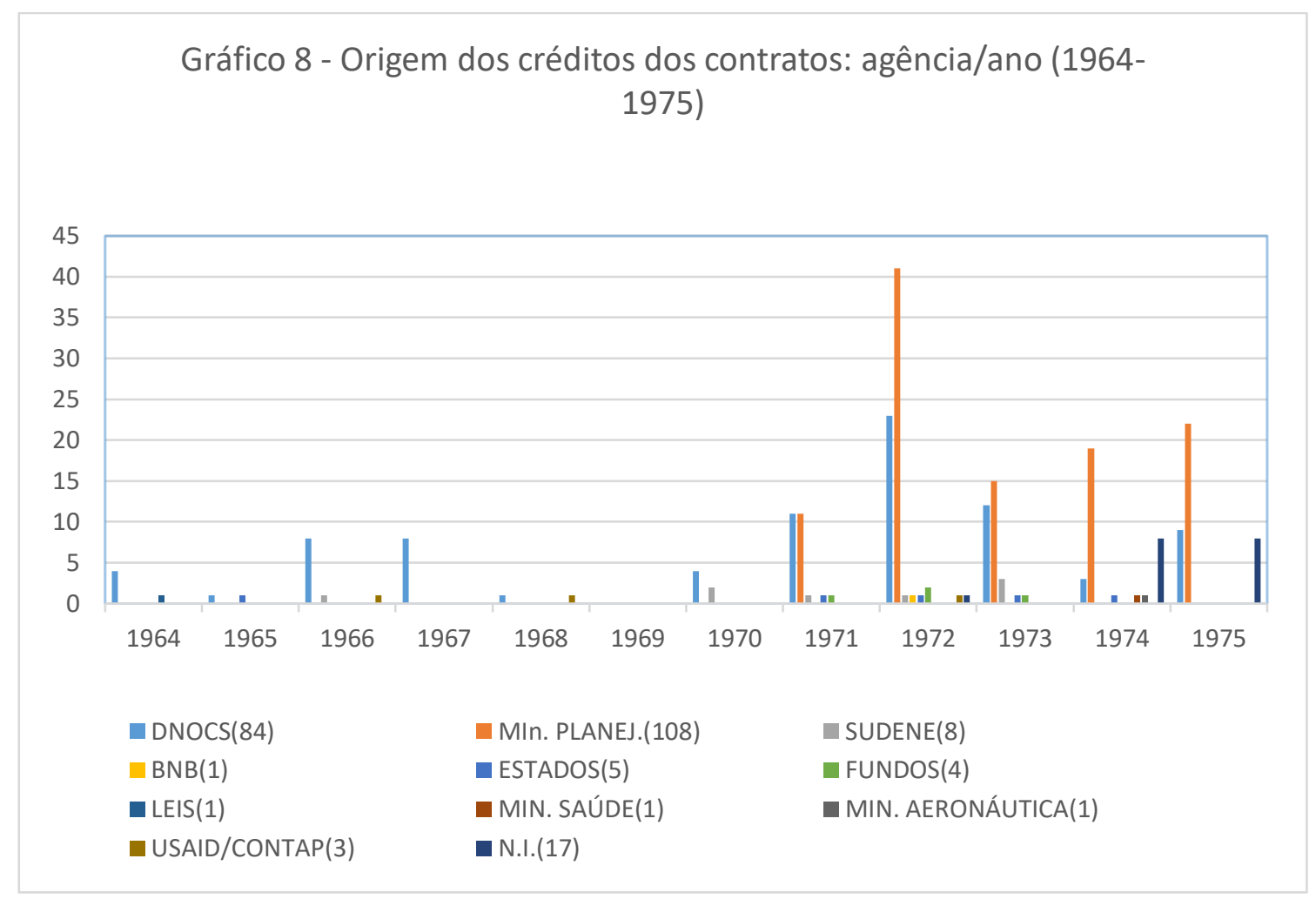

Fonte: Elaborado a partir dos livros de contratos do DNOCS (1964-1965).

Havia investimentos e financiamentos diretos à União, estados, a programas e projetos sem necessariamente serem declarados nas plataformas executoras e fiscalizadores. Daí uma das dificuldades de rastreamento e mapeamento das origens do endividamento brasileiro (FATORELLI, 2013). O PIN possuía como característica a possibilidade de captação de recursos externos e internos. O DNOCS, da mesma forma. Além disso, o DNOCS operou fundos, como - FUNOCS, que semelhantemente contava com financiamento privado, estrangeiro e nacional (BRASIL, 1963). Estes aspectos estavam em acordo com as diretrizes da política econômica iniciada com o golpe de 1964. Conforme Pires,

[...] um dos pilares fundamentais do Plano de Ação Econômica do Governo (PAEG) e das reformas econômicas que o acompanharam foi a definição de um novo padrão de financiamento para a economia em geral e para o Estado em particular. Esse novo padrão de financiamento lastreou-se em modificações institucionais relacionadas, essencialmente, à constituição de mecanismos apropriados para a captação de recursos externos e internos de forma não inflacionária. Em relação ao financiamento externo, a preocupação principal consistiu em permitir que o País se inserisse nos fluxos de capitais internacionais, oficiais e privados, notadamente no caso destes últimos, em franca 
expansão no período. Dessa forma, pretendia-se atenuar, simultaneamente, as restrições interna e externa. A consecução de tal objetivo foi possível, em primeiro lugar, pela própria mudança política, ao permitir que o ambiente político se tornasse agora mais "confiável" aos investidores externos; e, em segundo lugar, por meio de mudança legislativa, abrindo maiores oportunidades de acesso ao crédito externo. (PIRES, 2004, p. 551, grifos nosso)

A origem dos recursos nas fontes pagadoras e garantidoras dos contratos não foi registrada, evidentemente, nos acordos comerciais que analisamos. Assim, por um lado, se nos foi possível descobrir as fontes financiadoras dos contratos, conforme demonstrado no Gráfico 7, contudo, em virtude das limitações da própria documentação, tornou-se impossível escrutinar as origens dos recursos nas fontes pagadoras, embora saibamos, conforme apontado acima, que sua composição possuía valores de origem privada. Dito de outra maneira, isso ocorria por exemplo quando um contrato fazia referência ao PIN como fonte financiadora ou pagadora, mas não escrutinava a composição original desses recursos no próprio Programa; assim, os recursos poderiam ser tanto de origem privada como pública, dado que o PIN aceitava essa composição mista. Reiteramos, portanto, que o financiamento da iniciativa privada no setor agropecuário via instituições públicas, programas e projetos foi uma constante no período analisado.

Existem ainda outros marcos e sinalizadores que ampliam e endossam esta afirmação. A visita da comissão brasileira chefiado por Celso Furtado aos EUA referenciada acima, a participação na Aliança para o Progresso e a contratação de empréstimos multilaterais, a exemplo do Euromercado, são indícios importantes dessa nova dinâmica da arquitetura político-econômica montada que contribuiu para a ampliação da modernização agrícola no país.

O ano de 1966 é também significativo nesse sentido. Além das mudanças financeiras de abertura de mercado, o Estado, via Sudene, estimava um orçamento para o triênio vindouro (1966-1968) com participação de 50\% dos recursos de origem governamental e 50\% da iniciativa privada nacional e internacional'11. Importa lembrarmos que a Sudene, naquele período, projetava-se

\footnotetext{
11 III Plano Diretor de Desenvolvimento Econômico e Social do Nordeste - 1966 a 1968.

Disponível em: http://www.sudene.gov.br/acervo. Acesso em 13/05/2020.
} 
como a principal instituição brasileira responsável pelo fomento da agricultura irrigada no país (BORDENAVE, 1990), atuando concomitantemente e em parceria com as instituições aqui assinaladas ${ }^{12}$. Ampliava-se, portanto, as formas de participação do capital nas estratégias e ações tomadas pelo Estado para o setor agropecuário.

\section{Outra face da Revolução Verde: para além do tecnicismo}

Como observamos, a atividade agrícola deveria seguir os moldes da Revolução Verde: por um lado, a sua feição tecnicista com a implantação de novas culturas, insumos, fertilizantes, maquinário, enfim, os pacotes tecnológicos (MAZOYER; ROUDART, 2010); por outro lado, o verde da revolução das áreas irrigadas e o sistema de colonato deveriam bloquear o avanço do perigo vermelho (FONTES, 2010) de movimentos contestadores como as Ligas Camponesas:

Julião foi eleito deputado federal por Pernambuco, após ter sido deputado estadual naquele mesmo estado. Foi nesse momento que as ligas camponesas chegaram ao ápice de seu prestígio político [...]. Essa notoriedade se deveu em grande parte às repercussões internacionais das ligas. De fato, a Revolução Cubana alertou os políticos e a opinião pública dos EUA para os perigos de outros focos revolucionários semelhantes, e o temor recaiu sobre - Nordeste brasileiro, a mais extensa e povoada zona de pobreza do mundo ocidental. (CAMARGO, [20--])

Agrupavam-se, portanto, os interesses econômicos de estabelecer zonas agrícolas irrigadas e os interesses políticos de afastar os indivíduos de ideias subversivas. Entre os 35 perímetros irrigados operados pelo DNOCS, 29 foram constituídos no período ditatorial, resultando a desapropriação direta de 151.055,70 hectares (ALMEIDA et al., 2019). Nesse contexto, fica clara a importância dos contratos referentes à extensão rural e aos estudos e pesquisas. Através de convênios com as Instituições de Ensino Superior da região e do exterior, além da pesquisa sobre aspectos agropecuários, gestava-se uma aprendizagem direcionada, uma nova forma de ver e estar no mundo rural. Por meio do gerenciamento das áreas e associações, que administravam recursos e

\footnotetext{
${ }^{12}$ Encontramos nove contratos envolvendo a Sudene. BRASIL. DNOCS, Livros de contrato, $1964-$ 1965. Livro 1, fls. 73 e 102; livro 6, fl. 8v, livro 9, fl. 47v e 97; livro 11, fl. 7, livro 1.3, fls. 15, 21 e 43.
} 
eram responsáveis pela agenda da extensão rural, garantia-se ações para "utilização racional, difusão e correta aplicação de tecnologia adequada à irrigação" nos perímetros de irrigação (BRASIL, [197-c]).

A partir dos contratos constatamos que o Estado ditatorial operava pelo menos em dois frontes no âmbito rural: mediante a apropriação e administração dos meios naturais e através do controle das pessoas e dos recursos financeiros. E isso ocorria em atividades coordenadas com o capital, dado que, além dos empréstimos, a construção de todos os distritos de regadio envolveu firmas particulares, nacionais ou internacionais. Contudo, os resultados dos estudos e pesquisas destes trabalhos eram de "propriedade exclusiva" do DNOCS, cujo conteúdo era "confidencial" e estava relacionado às questões de Desenvolvimento e de Segurança Nacional (LIMA FILHO, 2011; SANTIAGO, 2012). ${ }^{13}$

Ao lado de questões estritamente técnicas, as pesquisas foram compostas por vários "Estudos de Viabilidade", como os referentes aos níveis social e econômico que escrutinaram a vida das populações rurais. ${ }^{14}$ Sob o argumento indenizatório, os(as) agricultores(as) e suas famílias eram averiguados e tinham suas vidas, habitações e demais bens devassados. Os investigadores percorriam as áreas delimitadas a se tornarem distritos irrigados bem como seus entornos. A partir daí puderam criar uma ampla cartografia de expurgo dos sujeitos e das práticas agrícolas tradicionais.

Os sujeitos devassados foram transpostos para cadernos de anotações, inventários e fichas de identificação pelos investigadores para, em seguida, serem sistematizados e incorporados à documentação oficial dos projetos de irrigação. Este material, referente a cada um dos 35 perímetros irrigados, foi entregue definitivamente ao DNOCS, como parte das prestações de contas das empresas e hoje é parte de seu acervo. ${ }^{15}$

Conforme os pensamentos e posicionamentos expostos nos depoimentos, alguns dos sujeitos identificados pelos investigadores eram classificados como

\footnotetext{
${ }^{13}$ Ver, por exemplo, o contrato estabelecido entre DNOCS e a italiana ITALCONSULT. DNOCS, Boletim Administrativo Regional, n 18 - DR2, 30/06/1972, p. 03.

${ }^{14}$ Ver: DNOCS, $2^{\circ}$ DR, Estudos de viabilidade e Projeto Executivo na Zona de Transição Tabuleiro de Russas Vale do Jaguaribe-CE, [198?].

${ }^{15}$ Consultar os "Estudos de Viabilidades" produzidos pelas empresas para cada uma das áreas desapropriadas disponíveis na Biblioteca do DNOCS, no município de Fortaleza, Ceará.
} 
"informantes"16 e assim apresentados pelas empresas ao Estado, via DNOCS, como nos casos de José Cândido e Jordão de Jesus, que, por razões diferentes, foram integrados aos relatórios oficiais referentes à construção do Perímetro Irrigado do Tabuleiro de Russas, no Ceará. O primeiro sujeito foi registrado pelo investigador em virtude dos aspectos positivos que tinha em mente frente à espera de realização do projeto de irrigação; enquanto o segundo era observado como um possível empecilho ao empreendimento, dado seu histórico de luta e suas concepções adversas sobre o projeto:

16 JOSÉ CÂNDIDO DA SILVA - proprietário (arrenda suas terras), lida com o comércio de produtos agrícolas, 70 anos, já foi desapropriado em Morada Nova. OBS. Entrevista iniciada com a esposa e finalizada com o próprio. [...] Tem uma história de lucro com a desapropriação feita em Morada Nova; atitude de espera frente às informações de uma nova desapropriação [...] $19^{\circ}$ JORDÃO DE JESUS DA SILVA - liderança comunitária; história do movimento de mobilização da região contra o projeto. Relato acerca de outros projetos que não deram certo; [relata a] perda da autonomia de muitos pela mudança da condição de ocupação. (BRASIL, [198?], p. 68-70).

Os "informantes" compunham uma seção específica denominada de "Resumo do discurso dos entrevistados" dentro dos "Estudos de Viabilidades". Através dela o investigador relatava sua interpretação sobre os territórios-alvo e suas avaliações sobre os depoentes. A escala utilizada pelos investigadores se dava no plano micro, mediante uma metodologia de inquirição porta a porta, de escrutínio dos bens mais íntimos daquelas pessoas registrados minunciosamente nos "Levantamentos Cadastrais" "17. O registro objetivo dos bens era acompanhado de uma avaliação subjetiva dos indivíduos pelo investigador que "de acordo com as principais questões emergentes" [buscava] "decodificar os sentimentos expressos no discurso desses sujeitos". (BRASIL, [198?], p. 40 e 46).

\footnotetext{
${ }^{16}$ A categoria "informante" esteve presente nos Estudos de Viabilidade Social e Econômica necessários para implantação dos 29 Perímetros Irrigados construídos no período ditatorial.

${ }_{17}$ O "Levantamento Cadastral" constituía um documento basilar para a identificação dos sujeitos relacionados aos territórios (proprietários, posseiros, rendeiros, moradores, etc.) e dos bens (casas, cisternas, áreas de cultivo, áreas de criação, etc.). Era a partir deste documento que se mensuravam os valores para ressarcimento nos processos de desapropriação, conforme demonstrado por Viana Júnior e Maupeou (2019). Agradecemos ao professor Diego Gadelha de Almeida que contribuiu na coleta e análise da documentação.
} 
Contemplava-se, por este caminho, outra das facetas da Revolução Verde: o controle e combate aos perigos do avanço comunista no espaço rural. Estes documentos confidenciais e repletos de informantes funcionaram não apenas como mapas de solos, relevos, hidrografia. Eram mapas político-ideológicos acerca do mundo rural brasileiro, permitindo o planejamento de ações do Estado e a identificação de possíveis inimigos a serem combatidos, como possivelmente Jordão de Jesus, marcado por sua história de luta e liderança comunitária. Os “inimigos” estavam na ordem do dia da concepção autoritária.

Existem outros movimentos dentro dos contratos que endossam esta proposição. Em janeiro de 1964, por exemplo, houve um acordo entre o DNOCS e a Civilmetal Construções Industriais S.A. para o fornecimento de comportas no Açude Público de Orós, no estado do Ceará. A cláusula onze abordava a regulamentação de multas à empresa em caso de descumprimento do contrato, salvo "[...] por motivo de força maior, como greves, "lock-out”, incêndios, guerras, revoluções." (BRASIL, [197-d]). Tratava-se, importante frisarmos, de um contrato firmado antes do golpe de 1964.

Oito anos mais tarde, em janeiro de 1971, já sedimentado e expandido o autoritarismo em diferentes frentes, a firma Construtora Salles Furlani Ltda. assumiu o compromisso, junto ao DNOCS, de desobstrução de drenos e sistematização de solos no Projeto de Irrigação Engenheiro Arcoverde, estado da Paraíba. Tal como no contrato anterior, havia uma cláusula que tratava de "casos fortuitos" e de "força maior". Nesse novo contexto, posterior à Lei de Segurança Nacional (Decreto-Lei 314/67), o significado das expressões ganhava novos contornos. Ao mesmo tempo em que repetia a preocupação sobre "greves e incêndios"; permutava o "lock-out, guerras e revoluções" por eufemismos genéricos de "comoções públicas e tumultos"; e acrescentava a expressão "atos de inimigos públicos" (BRASIL, [197-b]) que deveriam ser comunicados para análise e validação do DNOCS e, muito provavelmente, de outros órgãos como o Serviço Nacional de Informações $(\mathrm{SNI}){ }^{18}$

\footnotetext{
18 Esta descoberta foi realizada pela aluna e bolsista de iniciação científica Hortência Alves Nogueira.
} 
A incorporação de conceitos doutrinários da Escola Superior de Guerra (ESG) permitiu o delineamento da Segurança Nacional com foco na segurança externa e interna e que tinha como alvo aqueles que fossem considerados “inimigos” da consecução de objetivos nacionais (MATTOS; SWENSSON JR., 2003). Para tanto, a atuação do SNI foi fundamental, pois coordenava em solo nacional e estrangeiro as atividades de informação e contrainformação ao "[...] estabelecer comunicação com órgãos municipais, estaduais e federais do Poder Executivo e requisitar a colaboração de entidades privadas" (VIVIEN, 2012, p. 11).

Dito isto, observamos similitudes do formato institucional entre o DNOCS e o SNI, apesar de os objetivos e áreas de atuação dos dois órgãos serem bastante diferentes. Em ambos havia (i) a produção de conhecimento sobre territórios e populações de interesse do Estado autoritário; (ii) confidencialidade de documentos produzidos e coletados; (iii) colaboração de informantes e identificação de inimigos; (iv) comunicação e cooperação com outras instituições públicas municipais, estaduais e federais; ( $v$ ) e relações com empresas nacionais e internacionais.

São estes isomorfismos que nos sugerem uma aproximação entre os órgãos e apontam para relações mais profundas não declaradas entre eles. Ademais, o DNOCS dispunha de tecnologias, como a aerofotografia ${ }^{19}$, que auxiliavam nas atividades de interiorização das investigações do Estado; estabeleceu vários acordos com o Exército, principalmente com o Primeiro Grupamento de Engenharia ${ }^{20}$; e contou com diretores gerais alinhados ao Estado ditatorial e próximos, obviamente, do alto escalão governamental. O DNOCS, submetido à pasta do Ministério do Interior, teve ainda suas ações supervisionadas e direcionadas por sujeitos como o ministro Mário Andreazza. Este militar acumulava em seu currículo a passagem como tenente-coronel no Serviço Federal de Informações e Contrainformação (SFICI), "o primeiro serviço secreto brasileiro" (VIVIEN, 2012, p. 270).

\footnotetext{
${ }^{19}$ O DNOCS firmou dois contratos de recobrimento aerofotogramétrico. O primeiro foi acordado com a empresa Serviços Aerofotogramétricos Cruzeiro do Col S/A em 1970, e o segundo com a firma Geofoto no ano de 1972. DNOCS, Livros de Contrato, 1964-1975. Livro 9, fl. 71v; Livro 11, fl. 133.

20 Mapeamos oito contratos envolvendo o Exército brasileiro. DNOCS, Livros de Contrato, 19641975. Livro 1.4, fls. 14, 18v, 20, 26v; Livro 1.5, fls. 63v e 64v; Livro 9, fls. 7 e 134.
} 
As pesquisas e trabalhos técnicos executados pelo DNOCS e pelas empresas privadas contratadas sugerem-nos, portanto, um revestimento político concatenado aos objetivos persecutórios da ditadura civil-militar. Afinal, eram também as firmas responsáveis por garantir a segurança em suas áreas de atuação. Nossa proposição é que o desenho geopolítico de expansão da agricultura irrigada auxiliava a irrigar as investigações, produção de informações, arquivos e atividades do Estado autoritário compondo as múltiplas facetas da Revolução Verde no Nordeste brasileiro.

\section{Considerações finais}

Neste artigo retomamos e discutimos as características gerais da modernização agrícola no Brasil, com foco nas mudanças estruturais ocorridas na região Nordeste para a ampliação da área irrigada. Verificamos como estas transformações estiveram vinculadas à forte presença do Estado a partir de instituições, como o DNOCS e a SUDENE, e da iniciativa privada, mediante ação de credores e empresas executoras. Buscamos desvelar como o investimento no setor agrícola esteve relacionado ao endividamento do Estado brasileiro, através de investimentos internos e externos e pela captação de empréstimos para a execução de projetos e programas, a exemplo do Programa de Integração Nacional e do Programa Plurianual de Irrigação que marcaram as décadas de 1970 e 1980.

Observamos também como o empresariado nacional esteve atento às transformações estruturais na implantação da infraestrutura irrigada do país, aprovando legislação que o favoreceu e the garantiu forte participação na execução dos projetos. Em específico, para os contratos mediados pelo DNOCS, averiguamos como a modernização agrícola correspondeu ao principal setor de investimentos da autarquia e como isto esteve relacionado a formas de controle político-ideológico do Estado ditatorial.

A multiplicação dos distritos de irrigação no semiárido brasileiro possibilitou e foi possibilitada por um denso escrutínio das populações do campo. Isso atendeu tanto aos aspectos tecnicistas para a implantação do aparato material de regadio vinculados a interesses econômicos como aos 
objetivos políticos de mapeamento, controle e supervisão das populações rurais, desvelando as múltiplas facetas da Revolução Verde no Brasil, em acordo com os ditames autoritários da ditadura civil-militar.

As ações operadas no campo para a expansão da agricultura capitalista viabilizaram, portanto, a produção de amplo e denso conhecimento sobre territórios e sujeitos-alvo. E os isomorfismos de práticas de instituições como o DNOCS e o SNI, apesar de objetivos declaradamente diferentes, nos possibilitaram aventar a hipótese conjetural do compartilhamento de informações para a identificação e combate de inimigos públicos considerados pelo Estado.

Em suma, a investigação da expansão da Revolução Verde no período ditatorial brasileiro, com foco na estrutura de regadio, desvelou uma arquitetura política, econômica e social que teve seus pilares calcados no aprofundamento do endividamento do país, na produção de conhecimento sobre territórios e populações rurais e na ampliação de redes de controle e perseguição. Tal estrutura não apenas passou a irrigar os milhares de hectares desapropriados para construção de barragens e Perímetros de Irrigação. Muito provavelmente os arquivos ditatoriais foram inundados com as informações produzidas por empresas e instituições públicas voltadas para o setor agropecuário auxiliando no planejamento, na tomada de decisões e ações pela ditadura civil-militar.

\section{Referências}

ABLAS, Luiz. Agricultura irrigada e desenvolvimento regional. Revista Econômica Nordeste, Fortaleza, v. 19, n. 2, p. 155-174, abr./jun., 1988.

ABREU, Alzira Alves de. Plano nacional de desenvolvimento (PND). Rio de Janeiro: FGV DOC, [20--]. Disponível em:

http://www.fgv.br/cpdoc/acervo/dicionarios/verbete-tematico/plano-nacionalde-desenvolvimento-pnd._Acesso em: 24 ago. 2020.

ABREU, Marcelo de Paiva et al. A ordem do progresso: cem anos de política econômica republicana (1889-1989). Rio de Janeiro: Editora Campus, 1995.

ALMEIDA, Diego Gadelha de; VIANA JÚNIOR, Mário Martins; CHAVES, Rosa Lilian Sérvio de Carvalho; GOIS, Sarah Campelo Cruz. História, memória e conflitos 
territoriais no Ceará: comunidades do Tabuleiro de Russas. Fortaleza: EdUECE, 2019.

ANDRADE, Manuel Correia de. Tradição e mudança: a organização do espaço rural e urbano na área de irrigação do submédio São Francisco. Rio de Janeiro: Zahar, 1983.

ANDRADES, Thiago Oliveira de; GAMINI, Rosângela Nasser. Revolução verde e a apropriação capitalista, CES Revista, v.21 p.43-56, 2007.

BIZERRA, José Valdeci et al. Rentabilidade da irrigação pública no Nordeste sob condições de risco. Revista Econômica Nordeste, Fortaleza, v. 26, n. 2, p. 239263, abr./jun., 1989.

BRAGA, Ana Maria de Fátima Afonso. Tradição camponesa e modernização: experiências e memória dos colonos do perímetro irrigado de Morada Nova. CE. 2003. Dissertação (Mestrado em História Social) - Universidade Federal do Ceará, Fortaleza, 2003.

BRASIL. Lei no 4.229, de 10 de junho de 1963. Transforma o Departamento Nacional de Obras Contra as Sêcas (DNOCS) em autarquia e dá outras providências. Brasília: Presidência da República, 1963. Disponível em: https://www2.dnocs.gov.br/legislacao-2/item/12-lei-n-4-229-de-1-de-junho-de1963-transforma-o-dnocs-em-autarquia-e-da-outras-providencias. Acesso em: 04 jun. 2020.

BRASIL. Decreto-lei no 1.106, de 16 de junho de 1970. Cria o Programa de Integração Nacional, altera a legislação do imposto de renda das pessoas jurídicas na parte referente a incentivos fiscais e dá outras providências. Brasília: Presidência da República, 1970. Disponível em: http://www.planalto.gov.br/ccivil_03/Decreto-Lei/1965-1988/Del1106.htm. Acesso em: 04 jun. 2020

BRASIL. Ministério do Interior. GEIDA. Programa plurianual de irrigação (PPI). Brasília, 1971. 13v.

BRASIL. Departamento Nacional de Obras Contra as Secas. Livros de contrato, 1964-1975. [Fortaleza: DNOCS, 197-]. Livro 11. f. 1.

BRASIL. Departamento Nacional de Obras Contra as Secas. Livros de contrato, 1964-1975. [Fortaleza: DNOCS, 197-]. Livro 11. f. 56.

BRASIL. Departamento Nacional de Obras Contra as Secas. Livros de contrato, 1964-1975. [Fortaleza: DNOCS, 197-]. Livro 1. f. 36.

BRASIL. Departamento Nacional de Obras Contra as Secas. Livros de contrato, 1964-1975. [Fortaleza: DNOCS, 197-]. Livro 5, fl. 11v.

BRASIL. Departamento Nacional de Obras Contra as Secas, $2^{\circ}$ DR, Estudos de viabilidade e Projeto Executivo na Zona de Transição Tabuleiro de Russas Vale do Jaguaribe-CE, [198?]. p. 68-70. 
BRASIL. Ministério da Integração Nacional. A irrigação no Brasil: situação e diretrizes. Brasília: IICA, 2008.

BORDEVANE, Juan Días. Modernização da agricultura e cooperação internacional: 25 anos do IICA no Brasil. Brasília: Instituto interamericano de cooperação para a agricultura, 1990.

BURSZTYN, Marcel. O poder dos donos: planejamento, e clientelismo no Nordeste. Rio de Janeiro: Garamond; Fortaleza: BNB, 2008.

CAMARGO, Aspásia. Ligas camponesas. Rio de Janeiro: FGV DOC, [20--]. Disponível em: http://www.fgv.br/cpdoc/acervo/dicionarios/verbetetematico/ligas-camponesas. Acesso em: 04 ago. 2020.

CAMPOS, Pedro Henrique Pedreira. Estranhas catedrais: as empreiteiras brasileiras e a ditadura civil-militar, 1964-1988. Niterói: UFF, 2014.

COELHO NETO, Agripino Souza. Trajetórias e direcionamentos da política de irrigação no Brasil: as especificidades da região Nordeste e do Vale do São Francisco. Biblio 3w - Revista Bibliográfica de Geografía y Ciencias Sociales, v. XV, n. 876, p. 1-20, 2010.

DELGADO, Guilherme Costa. Expansão e modernização do setor agropecuário no pós-guerra: um estudo da reflexão agrária. Estud. av., São Paulo, v. 15, n. 43, p. 157-172, dec. 2001. Disponível em:

http://www.scielo.br/scielo.php?script=sci_arttext\&pid=S010340142001000300013\&lng=en\&nrm=iso. Acesso em: 04 jun. 2020.

DELGADO, Guilherme Costa. Capital e política agrária no Brasil: 1930-1980. In: SZMRECSÁNYI, Tamás; SUZIGAN, Wilson (orgs.) História econômica do Brasil contemporâneo. São Paulo: Hucitec: Associação Brasileira de Pesquisadores em História Econômica: Editora da Universidade de São Paulo: Imprensa Oficial, 2002.

DREIFUSS, René A. 1964, a conquista do Estado. Petrópolis: Vozes, 1981.

ENGENHARIA apoia novo decreto-lei. Correio da Manhã, Rio de Janeiro, ano 1969, n. 23.368, p. 6, 22 jun. 1969.

FATTORELLI, Maria Lucia. Auditoria cidadã da dívida pública: experiências e métodos. Brasília: Inove Editora, 2013.

FONTES, Virgínia. O Brasil e o capital imperialismo: teoria e história. Rio de Janeiro: EdUFRJ: Editora Escola Politécnica de Saúde Joaquim Venâncio, 2010.

GONÇALVES NETO, Wenceslau. Estado e agricultura no Brasil. Política agrícola e modernização econômica brasileira (1960-1980). São Paulo: HUCITEC, 1997.

IANNI, Octávio. A ditadura do grande capital. Rio de Janeiro: Civilização Brasileira, 1981. 
IBGE. Instituto Brasileiro de Geografia e Estatística. Censo agropecuário, séries históricas, máquinas, tratores ou equipamentos, 1970-1985. [Rio de Janeiro: IBGE, 198-]. Disponível em: https://sidra.ibge.gov.br/Tabela/1033. Acesso em: 04 jun. 2020.

IORIS, Antonio Augusto Rossotto. Da foz às Nascentes: análise histórica e apropriação econômica dos recursos hídricos no Brasil. In: ALMEIDA, Alfredo Wagner Berno de et al. Capitalismo globalizado e recursos territoriais: fronteiras da acumulação no Brasil contemporâneo. Rio de Janeiro: Lamparina, 2010.

KAGEYAMA, Angela et al. Estrutura agrária e irrigação no Nordeste. Revista Econômica Nordeste, Fortaleza, v. 20, n. 4, p. 431-452, out./dez. 1989.

LEME, Rosana Biral. Políticas estatais para a agricultura brasileira. Faz Ciência, v. 3, n. 01, p. 65-79, 1999.

LEMOS, Renato Luís do Couto Neto. Contrarrevolução e ditadura no Brasil: elementos para uma periodização do processo político brasileiro pós-64. In: CONGRĖS DU CEISAL, 6., 2010, Toulouse. (Conséil Européen de Recherche em Sciences Sociales sur l'Amerique Latine) - Indépendences, Dépendences, Interdépendences. Anais [...]. Toulouse: [CEISAL], 2010. 21 p.

LIMA, Jandir Ferreira de. Os recursos hídricos no Brasil: algumas considerações preliminares. Revista Econômica do Nordeste, Fortaleza, v. 30, n. 1, p. 64-75, jan./mar., 1999.

LIMA FILHO, Sebastião André Alves de. O que a escola superior de guerra (ESG) ensinava. 2001. 288p. Tese (Doutorado em Sociologia) - Universidade Federal do Ceará, Fortaleza, 2011.

LOUREIRO, Felipe. Empresários, Trabalhadores e Grupos de Interesse: a política econômica nos governos Jânio Quadros e João Goulart, 1961-1964. 2012. Tese (Doutorado em História) - Faculdade de Filosofia, Letras e Ciências Humanas da Universidade de São Paulo, São Paulo, 2012.

MARQUES, Luiz. Capitalismo e colapso ambiental. Campinas: Editora da Unicamp, 2015.

MATTOS, Marco Aurélio Vannuchi L. de; SWENSSON Jr., Walter Cruz. Contra os inimigos da ordem: a repressão política do regime militar brasileiro (1964-1985). Rio de Janeiro: DP\&A, 2003.

MAZOYER, Marcel; ROUDART, Laurence. História das agriculturas no mundo: do neolítico à crise contemporânea. São Paulo: Editora UNESP; Brasília, DF: NEAD, 2010.

MENDONÇA, Sonia Regina de. O ruralismo brasileiro (1888-1931). São Paulo: HUCITEC, 1997.

MENDONÇA, Sonia Regina de. O patronato rural no Brasil recente (1964-1993). Rio de Janeiro: UFRJ, 2009. 
MENDONÇA, Sonia Regina de. Extensão Rural e hegemonia norte-americana no Brasil. História Unisinos, v. 14, n. 2, p. 189-196, maio/ago. de 2010.

MENDONÇA, Sonia Regina de. Estado e políticas agrícolas na historiografia brasileira (1930-1964). In: SIMPÓSIO NACIONAL DE HISTÓRIA, 27., 2013, Natal. Anais eletrônicos [...]. Natal: [ANPUH], 2013, p. 0-13. Disponível em:

http://www.snh2013.anpuh.org/resources/anais/27/1363459588_ARQUIVO_trabal ho_SONIAMENDONCA_ST118.pdf. Acesso em: 10 abr. 2018.

MOLINA, Rodrigo Sarruge. Ditadura, agricultura e educação: a ESALQ/USP e a modernização conservadora do campo brasileiro (1964 a 1985). São Paulo: [s.n.], 2016.

OLIVEIRA, João do Carmo; MONTEZANO, Roberto Marcos da Silva. Os limites das fontes de financiamento à agricultura no Brasil. Estudos Econômicos, v. 12, n. 2, p. 139-159, ago. 1982.

OLIVEIRA, Pedro Cassiano Farias de Oliveira. Extensão rural e interesses patronais no Brasil: uma análise da Associação Brasileira de Crédito e Assistência Rural - ABCAR (1948-1974). 2013. 163 p. Dissertação (Mestrado em História) - Universidade Federal Fluminense, Rio de Janeiro, 2013.

PALHETA, Iraci Gomes de Vasconcelos et al. As políticas de irrigação no Nordeste: uma análise crítica. Revista do Departamento de Geografia, São Paulo: USP, v. 5, p. 39-46, 1991.

PEREIRA, João Márcio Mendes. O Banco Mundial como ator político, intelectual e financeiro (1944-2008). Rio de Janeiro: Civilização Brasileira, 2010.

PINTO, Magalhães. Magalhães faz teste. Jornal do Commercio, Rio de Janeiro, ano 1964, n. 235, p. 3, 12 jul. 1964.

PIRES, Julio Manuel. Uma visão histórica sobre o problema do padrão de financiamento da economia brasileira. Ensaios FEE, Porto Alegre, v. 25, n. 2, p. 545-560, out. 2004.

RAMOS, Simone Yuri; MARTHA JUNIOR, Geraldo Bueno. Evolução da política de crédito rural brasileira. Embrapa Cerrados: Planaltina, 2010.

RODRIGUEZ, Fernando Antônio (coord.). A irrigação no Brasil: situação e diretrizes. Brasília: Ministério da Integração Nacional, 2008.

SANTIAGO, Vandeck. Francisco Julião, as Ligas e o Golpe Militar de 1964 (2004). In: STÉDILE, João Pedro. A Questão Agrária no Brasil: história e natureza das Ligas Camponesas (1954-1964). São Paulo: Expressão Popular, 2012.

SERVILHA, Valdemar. O financiamento da agricultura brasileira. São Paulo: [s.n.], 1994.

SANTOS, José Vicente Tavares. Efeitos sociais da Modernização da Agricultura. In: SZMRECSÁNYI, Tamás; SUZIGAN, Wilson (orgs.) História econômica do Brasil 
contemporâneo. São Paulo: Hucitec: Associação Brasileira de Pesquisadores em História Econômica: Editora da Universidade de São Paulo: Imprensa Oficial, 2002.

SOUZA, Renival Alves; BARRIOS, José. Treinamento e pesquisa em agricultura irrigada no Nordeste do Brasil. Rio de Janeiro: IICA, 1974.

SZMRECSÁNYI, Tamás. O papel das políticas governamentais na modernização da agricultura brasileira. História \& Perspectivas. Uberlândia, v. 1, n. 10, p. 59-79, jan./jun.1994.

US\$125 milhões para Nordeste brasileiro. Jornal do Commercio, Rio de Janeiro, ano 1961, n. 237, p. 1, 15 jul. 1961.

VIANA JÚNIOR, MÁRIO MARTINS; MAUPEOU, Samuel Cavalheira de. Da produção camponesa familiar ao capitalismo: o perímetro irrigado Tabuleiro de Russas no Ceará (1988-2008). Tempos Históricos (Edunioeste), v. 22, p. 120-145, 2018.

VIVIEN, Ishaq. A escrita da repressão e da subversão, 1964-1985. Rio de Janeiro: Arquivo Nacional, 2012.

WRIGHT, Angus. Descendo a montanha e seguindo para o norte: como a degradação do solo e os pesticidas sintéticos orientaram a trajetória da agricultura mexicana ao longo do século XX. Topoi, v. 13, n. 24, p. 136-161, jan./jun. 2012 